Assessing fossil and new carbon in reclaimed mined soils

Investigators: Professor Rattan Lal and Dr. David A.N. Ussiri

\title{
Final Scientific Technical report
}

DOE Award No: DE-FC26-04NT42208

Project Start Date: September 1, 2004

Project End Date: September 30, 2008

Authors: David A.N. Ussiri and Rattan Lal

Date Report was issued: November, 2008

\section{The Ohio State University Research Foundation}

1960 Kenny Road, Columbus, OH 43210-1063 


\section{DISCLAIMER}

This report was prepared as an account of work sponsored by an agency of the United States Government. Neither the United States Government nor any agency thereof nor any of their employees makes any warranty, express or implied or assumes any legal liability or responsibility for the accuracy, completeness or usefulness of any information, apparatus product or process disclosed, or represents that its use would infringe privately owned rights. Reference herein to any specific commercial product, process or service by trade name, manufacturer, or otherwise does not necessarily constitute or imply its endorsement, recommendation, or favoring by United States Government or any agents thereof. The views and opinions of authors expressed herein do not necessarily state or reflect those of the United States Government or any agents thereof. 


\section{ABSTRACT}

Soil organic carbon (SOC) pool in the reclaimed minesoils (RMS) is the mixture of coal C originating from mining and reclamation activities and recent plant-derived organic carbon (OC). Accurate estimates of OC pools and sequestration rates in the RMS are limited by lack of standard and cost-effective method for determination of coal-C concentration. The main objective of this project was to develop and test analytical procedures for quantifying pool sizes of coal-derived C in RMS and to partition organic C in RMS into coal-derived and newly deposited SOC fractions. Analysis of soil and coal artificial mixtures indicated that the $\delta^{13} \mathrm{C}$ method developed was very effective in estimating coal $\mathrm{C}$ added in the mixtures, especially soils under C4 plants. However, most of the reclaimed sites in Ohio are under C3 plants with range of $\delta^{13} \mathrm{C}$ signal falling within ranges of coal. The wide range of $\delta^{13} \mathrm{C}$ signal observed in minesoils, (i.e. -26 to -30 for plants and -23 to -26 for coal) limits the ability of this approach to be used for southeast Ohio minesoils. This method is applicable for reclaimed prime farm land under long term corn or corn soybean rotation. Chemi-thermal method was very effective in quantifying coal-C fraction in both soil-coal artificial mixtures and minesoils. The recovery of coal-C from the mixture ranged from 93 to $100 \%$ of coal. Cross-validation of chemi-thermal method with radiocarbon analysis revealed that chemi-thermal method was as effective as radiocarbon analysis in quantifying coal-C in RMS. Coal C determined after chemi-thermal treatment of samples was highly correlated with coal $\mathrm{C}$ concentration calculated by radiocarbon activity $\left(\mathrm{r}^{2}=\right.$ $0.95, \mathrm{P}<0.01)$. Therefore, both radiocarbon activity and chemi-thermal method were effective in estimating coal carbon concentration in reclaimed minesoils of southeast Ohio. Overall, both coal-C and recent OC fraction exhibited high spatial and depth variation, suggesting that approaches used to obtain representative samples in undisturbed soils may not be effective in 
RMS sites. Analysis of coal-C fraction in RMS indicated that the contribution of coal C to SOC increased with increase in soil depth, accounting for up to $92 \%$ of SOC in the sub-soil. Our data indicated that land use and land management practices plays significant role in enhancing SOC sequestration in reclaimed mined lands. 


\section{TABLE OF CONTENTS}

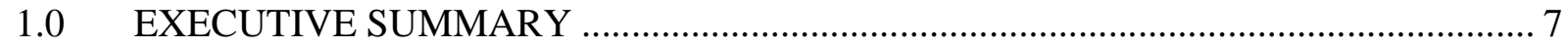

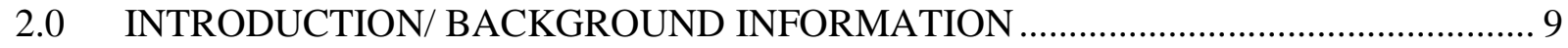

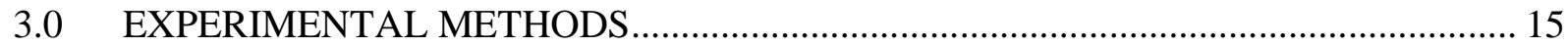

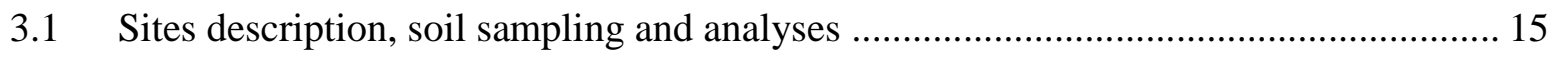

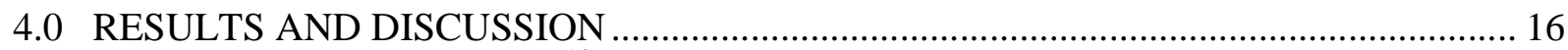

4.1 Task 1: Development of ${ }^{13} \mathrm{C}$-based procedure to determine the fraction of coal-C

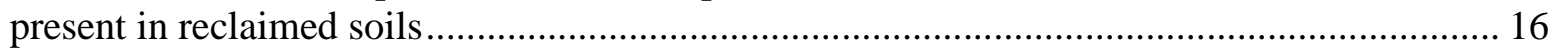

3.2.1 Samples Pretreatment, Elemental and stable carbon isotope Analysis ................... 16

4.1.2 Calculation of coal-C and recent $\mathrm{OC}$ fractions .................................................. 18

4.1.3 Analysis of soil and coal mixtures of known composition .................................. 18

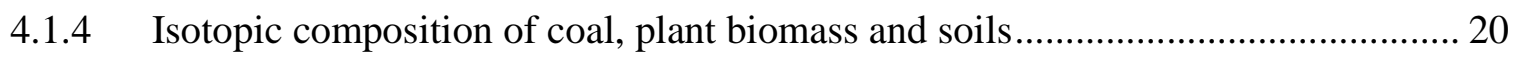

4.2 Task 2: Development of Chemi-thermal procedure to quantify coal-derived $\mathrm{C}$ and

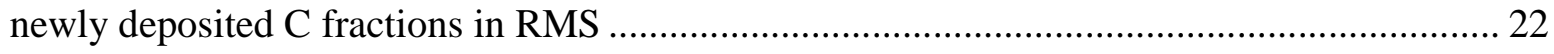

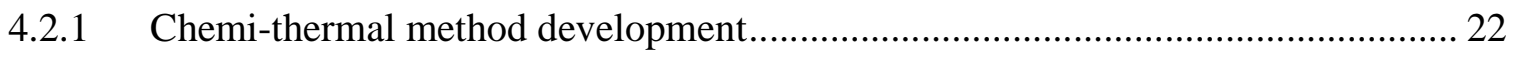

4.2.2 Chemi-thermal treatment of soil and coal mixtures............................................. 24

4.2.3 Chemi-thermal treatment of reclaimed minesoils ................................................ 25

4.3 Task 3: Cross-validation of ${ }^{13} \mathrm{C}$-based and chemi-thermal procedures to assess coal-C

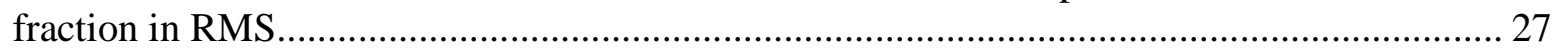

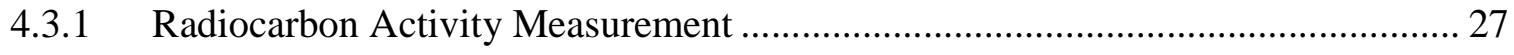

4.3.2 Calculation of SOM Age and Radiocarbon Activity .......................................... 27

4.3.3 Coal $\mathrm{C}$ and recent $\mathrm{OC}$ fractions of the soil and coal mixtures ............................... 29

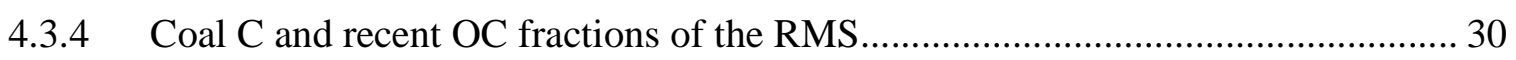

4.3.5 Comparison of stable $\mathrm{C}$ isotope ratio, chemi-thermal and radiocarbon analysis

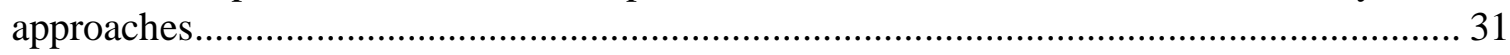

4.3.6 Relationship Between ${ }^{14} \mathrm{C}$ Activity Analysis and Chemi-thermal Method ........... 32

4.4 Task 4: Optimum sampling design and distribution of coal particles within the profiles

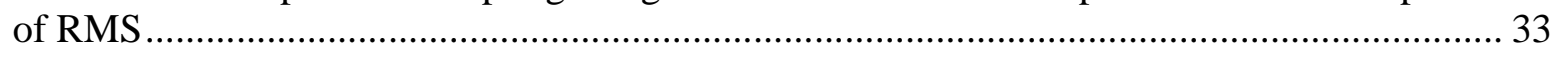

4.4.1 Variability of bulk density, soil $\mathrm{N}$ and different $\mathrm{C}$ fractions in RMS .................... 33

4.1.2 Soil organic $\mathrm{C}$ and nitrogen pools in different land use...................................... 39

4.4.3 Soil organic carbon pool and sequestration rates............................................... 41

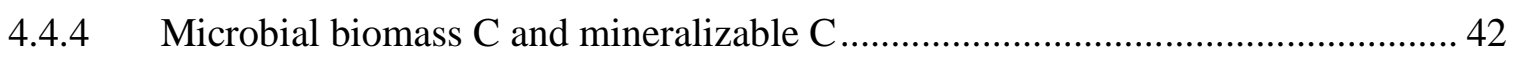

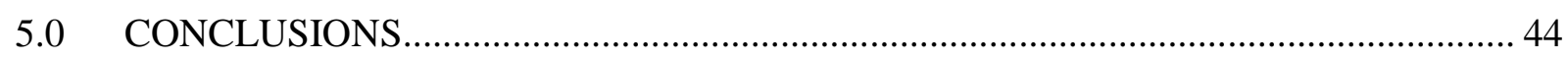

List of Publications and scientific presentations from this project .......................................... 45

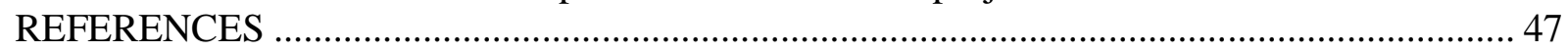




\section{LIST OF TABLES}

Table 1. Calculated and actual coal-derived $\mathrm{C}$ in soil coal mixtures computed based on the $\delta^{13} \mathrm{C}$

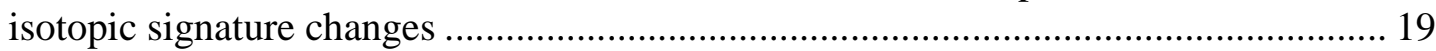

Table 2. Stable isotope composition of coal and plant litter.................................................. 20

Table 3. Concentration of coal, and recent OC estimated by isotope mixed model in the RMS (mean \pm standard deviation).....

Table 4. Estimated coal $\mathrm{C}$ concentration based on $\delta^{13} \mathrm{C}$ isotopic signature changes after chemithermal treatment to remove recent organic matter.............................................. 25

Table 5. Effects of chemi-thermal treatment on organic carbon of the reclaimed minesoils. ...... 26

Table 6. Radiocarbon age, vegetation- and coal-derived carbon contribution to total organic carbon in the RMS (numbers in brackets are standard errors)....................................2 29

Table 7. Descriptive statistics for bulk density at different depths in reclaimed sites $\left(\mathrm{Mg} \mathrm{m}^{-3}\right)$.. 34

Table 8. Descriptive statistics for Coal $\mathrm{C}$ pool at different depths in reclaimed sites $\left(\mathrm{Mg} \mathrm{ha}^{-1}\right) . .35$

Table 9. Descriptive statistics for inorganic $\mathrm{C}$ pool in reclaimed sites $\left(\mathrm{Mg} \mathrm{ha}^{-1}\right)$........................ 37

Table 10. Descriptive statistics for SOC pool at different depths in reclaimed sites $\left(\mathrm{Mg} \mathrm{ha}^{-1}\right) \ldots 38$

Table 11. Soil organic $\mathrm{C}$ concentration of the top $50 \mathrm{~cm}$ in the age chronosequence of pastures in RMS of Northeast Ohio. .......................................................................................... 41

Table 12. Recent soil organic carbon sequestration rates established from age chronosequence of pasture from eastern Ohio....................................................................................... 42

\section{LIST OF FIGURES}

Figure 1. Summary of the steps and processes for removing recent organic carbon for coalderived $\mathrm{C}$ quantification in RMS. .

Figure 2. Relationship between coal-C fractions of soil-coal mixtures determined by $\delta^{13} \mathrm{C}$ and chemi-thermal methods.

Figure 3. Relationship between coal-C fraction of the reclaimed mined soils determined by radiocarbon activity and chemi-thermal method

Figure 4. Total $\mathrm{N}$ pool in the top $50 \mathrm{~cm}$ of the reclaimed minesoils of Ohio under various land uses......

Figure 5. Soil organic $\mathrm{C}$ pools in the top $50 \mathrm{~cm}$ of the reclaimed mine soils of Ohio under various land uses.

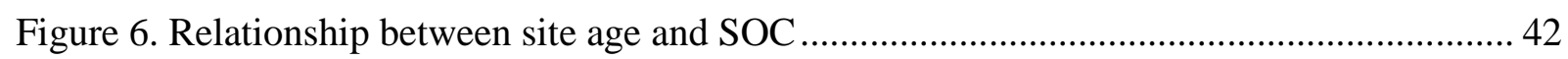

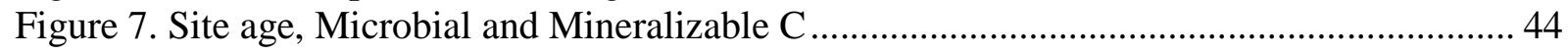




\subsection{EXECUTIVE SUMMARY}

This research project was supported by the US Department of Energy (US-DOE). The objectives were to: (i) developing and testing analytical procedures to quantify pool sizes of coalderived $\mathrm{C}$ in reclaimed minesoils (RMS), and partition total $\mathrm{C}$ in RMS into soil inorganic carbon (SIC), coal derived (Coal-C) and newly deposited organic carbon (recent OC) fractions, (ii) developing a ${ }^{13} \mathrm{C}$ isotope based procedure for determining the amount of coal $\mathrm{C}$ in reclaimed mine soils and validation of other procedures, and (iii) establishing optimum sampling protocol to produce adequate assessment of $\mathrm{C}$ sequestration in RMS of southeastern Ohio.

The OC present in reclaimed minesoils is a mixture of carbonaceous materials comprising: (1) fractions of recent biomass origin referred to in this report as recent soil organic carbon (recent OC), and (2) coal particles dispersed during mining and reclamation operations referred to in this report as coal- C. Coal contributes an unknown amount to SOC assessment in RMS, which makes it difficult to determine $\mathrm{C}$ additions due to the recent decomposition of plant materials in RMS. Differentiation of coal $\mathrm{C}$ and recent $\mathrm{C}$ is necessary for quantification of the rate of accumulation of recent OC in RMS during soil genesis and to assess the potential of RMS for $\mathrm{C}$ sequestration in RMS. Few, if any, studies have been carried out to quantify $\mathrm{C}$ derived from coal remains in the minesoils of Ohio, mainly due to lack of standard inexpensive method for quantifying coal-C. Radiocarbon analysis $\left({ }^{14} \mathrm{C}\right.$ analysis, carbon dating) is the commonly used method for quantifying coal $\mathrm{C}$ concentration accurately in RMS. However, high analytical costs preclude adoption of this method for routine soil analyses. Two approaches, $\delta^{13} \mathrm{C}$ analysis, and chemi-thermal methods were developed and tested with soil-coal mixtures and minesoils from southeast Ohio. The methods were also cross-validated with radiocarbon analysis.

Analysis of soil and coal artificial mixtures indicated that the $\delta^{13} \mathrm{C}$ method developed was very effective in estimating coal $\mathrm{C}$ added in the mixtures of soil and coal. the approach was more effective for soils under $\mathrm{C} 4$ plants. However, most of the reclaimed sites in Ohio are under C3 plants with range of $\delta^{13} \mathrm{C}$ signal falling within ranges of coal. The wide range of $\delta^{13} \mathrm{C}$ signal observed in minesoils, (i.e. -26 to -30 for plants and -23 to -26 for coal) limits the ability of this approach to be used for southeast Ohio minesoils. This method may be applicable for reclaimed prime farm land under long term corn or corn soybean rotation. Chemi-thermal method was very effective in quantifying coal- $\mathrm{C}$ fraction in both soil-coal artificial mixtures and minesoils. The recovery of coal-C from the mixture ranged from 93 to $100 \%$ of coal.

Radiocarbon measurement is useful tool for quantification of coal $\mathrm{C}$ contribution to the TOC in the reclaimed minesoils contaminated with coal. Cross-validation of chemi-thermal method with radiocarbon analysis revealed that chemi-thermal method was as effective as radiocarbon analysis in quantifying coal-C in RMS. Analysis of coal and soil mixtures indicated that the radiocarbon age increased with increasing coal $\mathrm{C}$ concentration. Radiocarbon analysis indicated that coal $\mathrm{C}$ contribution to SOC increased with increase in soil depth, accounting for up to $92 \%$ of SOC in the subsoil of the reclaimed minesoils. The ${ }^{14} \mathrm{C}$ age of SOM increased with increasing depth due to presence of coal C. Coal C contribution to TOC strongly influenced the stable isotope composition of SOM. Residual C determined after chemi-thermal treatment of samples was highly correlated with coal $\mathrm{C}$ concentration calculated by radiocarbon activity $\left(\mathrm{r}^{2}=\right.$ $0.95, \mathrm{P}<0.01)$. Therefore, both radiocarbon activity and chemi-thermal method were effective in estimating coal carbon concentration in reclaimed minesoils of southeast Ohio.

Overall, both coal-C and recent OC fraction exhibited high spatial and depth variation, suggesting that approaches used to obtain representative samples in undisturbed soils may not be 
effective in RMS sites. Our data indicated that land use and land management practices plays significant role in enhancing SOC sequestration in reclaimed mined lands. 


\subsection{INTRODUCTION/ BACKGROUND INFORMATION}

Atmospheric concentration of $\mathrm{CO}_{2}$ has increased from $280 \mathrm{ppm}$ in the pre-industrial era around 1750 to 367 ppm in 1999 (IPCC, 2001) and 382 ppm in 2006 (WMO, 2007). The increase in concentration of $\mathrm{CO}_{2}$ and other GHGs has been linked to the current and projected global climate change. Fossil fuel combustion and land-use change are the primary sources of atmospheric abundance of $\mathrm{CO}_{2}$. The projected temperature rise of 1.5 to $4.5^{\circ} \mathrm{C}$ with the doubling of $\mathrm{CO}_{2}$ concentrations (IPCC, 2001; 2007) could have drastic biological and socio-economic impacts worldwide. Coal, used for power, heat, industry and transport, makes an important contribution to economic and social development in USA and worldwide. Coal accounts for $95 \%$ of fossil energy reserve, supplies 50 percent of U.S. electricity needs, and is expected to remain an important fuel for decades (OSM, 2003; NMA, 2007); Therefore, coal is, and will continue to be the backbone of the coalproducing States and USA's economy. However, its environmental impact remains a challenge. The continuing demand for fossil fuel-based power and the associated increase in atmospheric $\mathrm{CO}_{2}$ concentration necessitates offsetting $\mathrm{CO}_{2}$ emissions.

Carbon sequestration is one of the strategies for stabilization of atmospheric $\mathrm{CO}_{2}$ abundance. It is defined as the long-term transfer of atmospheric $\mathrm{CO}_{2}$ into terrestrial (soil and biota), geologic and oceanic pools and subsequent long-term storage so that it is not re-emitted into the atmosphere (DOE, 1999; Lal et al., 2003). The $\mathrm{C}$ sequestration process can be biotic or abiotic. Abiotic sequestration involves separating, and injecting $\mathrm{CO}_{2}$ from industrial sources into oceanic or geologic strata (DOE, 1999). Biotic sequestration involves removal of atmospheric $\mathrm{CO}_{2}$ by chlorophyll-bearing plants through photosynthetic fixation and the conversion of some photosynthesized $\mathrm{C}$ into long-term storage, both standing plant biomass, SOC and aquatic pools (DOE, 1999). Terrestrial C sequestration captures atmospheric $\mathrm{CO}_{2}$ through photosynthesis and stores it into SOC pools through humification of plant biomass. Carbon gained through photosynthesis is initially partitioned within various aboveground and belowground compartments and then transformed from live to dead organic matter. Carbon represents roughly one half 
of the mass of live biomass and detrital SOM pools. Enhancing terrestrial C sequestration as the mechanism for removing $\mathrm{CO}_{2}$ from the atmosphere is a cost-effective mean of off-setting fossil fuel emissions with minimal risks (Lal, 2004).

Surface mining is the common technique used for coal mining in southeast Ohio due to occurrence of coal seams at shallow depths. It involves removal of vegetation, scraping of topsoil and stockpiling it for topsoiling during the reclamation process. The overburden material (subsoil, weathered material and rock fragments overlaying the coal seams) is blasted into a consolidated spoil using explosives and removed to expose the coal bed. Surface mining, therefore, causes drastic land disturbance and land degradation on large area, and generates large volume of freshly blasted mine spoils. The resulting sites cannot completely restore themselves through normal secondary succession, causing major damage to the entire ecosystem, thereby necessitating managerial reclamation.

Mine land reclamation involves backfilling of the mining pit with spoil and grading it to the original contour, replacing topsoil and/or applying plant growth media and/or soil amendments, and finally establishing vegetation cover. Once the mine spoils are reclaimed and utilized to grow plants, either with or without topsoil application, the recreated land is called 'reclaimed minesoils' or RMSs (Sencindiver and Ammons, 2000). Therefore, RMSs are soils formed on landscapes altered by mining activities, and are called manmade or anthropogenic soils (Lal et al., 2004). The RMSs are pedogenically young soils that are developing from mine spoils (i.e. fragmented rocks and subsoil mixture). These materials are often less weathered than the original soils. Rapid weathering of spoil develops soils with properties that differ greatly from the original undisturbed soil (Sencindiver and Ammons, 2000). Extreme disturbance during mining causes drastic perturbations in the original soil profile, leading to severe soil degradation. The sudden mining perturbation gives little time for soil's inherent resilience to respond. Severe 
loss of SOM leads to decline in soil quality and its functions (Lal et al., 1997). Much of SOM losses can be attributed to lack of inputs from plant litter, loss of topsoil, mechanical mixing of $\mathrm{A}, \mathrm{B}$, and $\mathrm{C}$ horizons during removal and handling of overburden material, accelerated erosion, leaching and accentuated decomposition of SOM from the exposed topsoil during stockpiling. Similar to tillage, topsoil scraping during surface mining, in addition to mixing and stirring of soil, breaks up aggregates and exposes organo-mineral surfaces otherwise inaccessible to decomposers. The RMSs are often characterized by low levels of key nutrients, unfavorable $\mathrm{pH}$, poor soil structure, high bulk density (1.55-1.86 $\mathrm{Mg} \mathrm{m}^{-3}$ ), high rock fragments (33-45\%), low water holding capacity, and low biomass productivity(Indorante et al., 1981; Haering et al., 2000;Seybold et al., 2004; Shrestha and Lal, 2006). These drastically disturbed soils have high potential for C sequestration (Akala and Lal, 2001; Ussiri et al., 2006a, b; Sperow, 2006). Proper reclamation and post-reclamation management may further enhance $\mathrm{C}$ sequestration and increase the economic value of RMSs.

Nearly 3.2 Mha (million hectares or 7.9 million acres) of land have been disturbed by coal mining activities across the U.S. (OSM, 2004), and coal combustion in the USA emitted 2104 MT (1 MT = million metric ton) of $\mathrm{CO}_{2}$ equivalent in 2004 (EIA, 2006). However, there is a great uncertainty regarding pools and rates of C sequestration in RMS. Reported rates of C sequestration are generally higher than those reported from cropland and forest soils, raising questions about their accuracy. This uncertainty results from (i) the failure to account for contribution of coal particles to the soil organic C pool, (ii) lack of standard method for quantifying coal C, and (iii) lack of standard protocols for sampling, given the variability of soil properties at the RMS sites.

Minesoils formed from reclamation of surface-mined sites for coal are characterized by the 
presence of intrinsically stable forms of organic carbon (OC) derived from coal (Schafer et al., 1980; Stroo and Jencks, 1982; Insam and Domsch, 1988; Roberts et al., 1988; Rumpel et al., 1998b) which cannot be separated from these soils by physical means. This geogenic carbon, (i.e. OC subjected to geological processes), is the result of coal particles incorporated with spoil during overburden removal, coal mining and reclamation operations, and coal dust particles dispersed during coal mining and reclamation processes. In addition, inorganic carbonates may also occur in significant concentrations, depending on the parent material type. Therefore, total carbon (TC) in reclaimed minesoils (RMS) is usually a mixture of: (1) soil inorganic carbon (SIC) originating from parent material, (2) coal $\mathrm{C}$ or geogenic $\mathrm{C}$ from mining and reclamation operations, and (3) plant-derived recent soil organic carbon (SOC).

In these sites, OM derived from plant material occurs in intimate mixture with coal from the overburden material. Because of the dark color of humus formed by decomposition of plant litter, and fine sized coal particles, coal may not be distinguished from humus materials by morphological observations. Differentiation of coal and recent $\mathrm{C}$ is crucial for quantification of the accumulation of recent SOC during soil genesis, evaluating $\mathrm{C}$ sequestration potential, ecosystem function and assessing the degree of humification in these sites.

Research efforts to quantify the contribution of coal-derived carbon to the total organic C (TOC) concentration in the RMS are few. (Rumpel et al., 1998b) examined the types of C present in minesoils landscapes of Lusatia mining district in Germany and showed, after quantification of lignite $\mathrm{C}$ content by ${ }^{14} \mathrm{C}$ activity measurement that, $\mathrm{OC}$ of the subsoil of the minesoils was almost exclusively composed of lignite $\mathrm{C}$, while up to $50 \%$ of all $\mathrm{C}$ originated from lignite in the A-horizon. In East Germany, areas heavily contaminated by fly-ash, soot and 
lignite dust, lignite-derived material accounted for up to $40 \%$ of OC of the forest floor (Rumpel et al., 1998a) and up to $80 \%$ of the soil carbon of an agricultural soil (Schmidt et al., 1996).

Carbon derived from coal and recent plant OC can be quantitatively estimated by radiocarbon $\left({ }^{14} \mathrm{C}\right)$ activity (Rumpel et al., 1998b, 2000, 2003; Fettweis et al., 2005; Chabbi et al., 2006). However, the utility of this method is limited for routine soil analysis due to high analytical cost and limited availability of the facilities needed for the analysis. The overall objective of this project was to address the methodological and technical gaps by developing the analytical methods for quantifying coal-derived $\mathrm{C}$ in under RMS conditions. The specific objectives of the project were to:

i. Develop and test a ${ }^{13} \mathrm{C}$-based procedure to quantify the fraction of coal-C present in reclaimed minesoils.

ii. Evaluate chemi-thermo procedure based on the greater recalcitrance of coal than recent $\mathrm{C}$ pools, to partition organic $\mathrm{C}$ in reclaimed soils into coal-derived and recent organic carbon fractions.

iii. Establish an optimum sampling protocol to produce accurate assessment of C sequestration in reclaimed mined soils.

One of the major limitations encountered in studies of dynamics of recent SOC in minesoils is lack of standard method for adjusting the OC concentration for coal C. Several techniques, including microscopic examination and manual separation, spectroscopy and chemical oxidation/fractionation have been proposed to differentiate between fossil and recent OC in RMS. Chemical methods involve removal of recent OC by various chemical treatments, including oxidation (peroxide, potassium dichromate, and thermal oxidation) and extraction with mild alkaline solutions allowing the assessment of refractory OC, mainly coal C (Schmidt et al., 
2001). The major limitation of chemical methods is the inability for the chemical methods to remove stabilized OC, therefore over-estimation of coal C. Spectroscopic methods generally fractionate recent and fossil $\mathrm{C}$ based on relative abundance of specific functional groups. While recent OC is mainly composed of carbohydrates, protein, lignin and lipids, coal C contains considerable portions of aliphatic and aromatic structures which are formed during coalification. Structural analysis by ${ }^{13} \mathrm{C}$ nuclear magnetic resonance (NMR) spectroscopy has been used to provide an indication of lignite C contribution to soils (Schmidt et al., 1996, Rumpel et al., 1998b, 1999). However, due to overlapping signals in the spectra, quantitative estimates of the lignite to the spectra cannot be achieved. Therefore NMR spectroscopy method is only qualitative. Radiocarbon measurement technique is the commonly used technique for quantification of coal C. Coal is composed of $\mathrm{C}$ which was deposited several million years ago, therefore consisting of stable carbon isotopes (i.e. no radiocarbon activity). Radiocarbon analysis (radiocarbon dating) has been used successfully to quantify lignite $\mathrm{C}$ concentration in RMS (Rumpel et al., 1998b, 2003). However, high analytical costs preclude adoption of this method for routine soil analysis.

Natural isotopic variation results from $\mathrm{C}$ isotope fractionation during photosynthesis (Farquhar, 1989), largely as a result of biochemical properties of the primary $\mathrm{CO}_{2}$-fixing enzymes and limitation to $\mathrm{CO}_{2}$ diffusion into leaf (O'Leary, 1989). Terrestrial plants are divided into three major photosynthesis types, based on their unique $\mathrm{C}$ isotope fractionation patterns, namely: (1) $\mathrm{C}_{3}$ plants, with the enzyme which discriminate against ${ }^{13} \mathrm{CO}_{2}$ during photosynthesis process, resulting into low $\delta^{13} \mathrm{C}\left(-35\right.$ to $-22 \%$, mean $-27 \%$ o), (2) $\mathrm{C}_{4}$ plants, with the enzyme which does not discriminate against ${ }^{13} \mathrm{C}$, therefore plants have relatively higher $\delta^{13} \mathrm{C}$ (-19 to $-9 \%$, mean $=-12 \%$ o), and (3) Plants with Crassulacean acid metabolism (CAM) which are able to 
switch between $\mathrm{C}_{3}$ and $\mathrm{C}_{4}$ pathways under certain environmental conditions, and have $\delta^{13} \mathrm{C}$ values dependent on the relative proportions of $\mathrm{C}$ fixed by each pathway ( -28 to-10\%, Grifith, 1992). These natural isotopic differences allow $C$ derived from each photosynthetic pathway to be traced through above-ground biomass and into the soil organic matter (SOM). The ${ }^{13} \mathrm{C}$ natural abundance of SOM corresponds closely to that of the vegetation from which it originated, and where the vegetation has been compositionally stable, the $\delta^{13} \mathrm{C}$ value of SOM in the upper profile is similar to that of the plant community (Balesdent et al., 1993).

The ${ }^{13} \mathrm{C}$ abundance of reclaimed minesoils reflects that of, inorganic (carbonates) and organic (coal $\mathrm{C}$ and the recent $\mathrm{OC}$ deposited mainly as detritus from plants). Acid treatment of a soil sample displaces carbonate/bicarbonate, which is released as $\mathrm{CO}_{2}$ (Loeppert and Suarez, 1996). This isotope mixing effects can be utilized to separate OC in minesoils into coal and current vegetation origins by exploiting the differences in stable $\mathrm{C}$ isotope composition between coal and plant biomass which contributed to SOC contents of minesoils.

\subsection{EXPERIMENTAL METHODS:}

\subsection{Sites description, soil sampling and analyses}

Experimental sites were selected in four counties in eastern Ohio comprised of Harrison (Cadiz), Muskingum (High Hill), Morgan (Mount Carmel), and Noble (Brooksfield). All sites, except Cadiz, are owned by American Electric Power (AEP). Two post-reclamation land uses pasture/grassland and forest of similar age since reclamation were selected within similar soil types for this study. In addition, a chronosequence of grassland sites ranging from 1 to 30 years since reclamation was selected at Cadiz, which is owned and operated by CONSOL. Soil samples were obtained in triplicate for each location. An undisturbed site nearby with similar pre-mining soil series under similar land use was also sampled for control. Bulk soil 
samples were collected from 0-5, 5-10, 10-20, 20-30, 30-40, and 40-50 cm depth. In addition, core samples were obtained for each location at each depth interval for bulk density determination. Sampling locations were selected randomly along transects to reflect variations in slope. Soil samples were transported to OSU for processing and analyses. Bulk soil samples were air-dried, ground and sieved through a 2-mm sieve. A sub sample ( $2 \mathrm{~g})$ of each was finely ground to pass through a $0.25 \mathrm{~mm}$ sieve for total organic carbon (TOC) and total nitrogen (TN) determinations. Concentration of $\mathrm{C}$ and $\mathrm{N}$ were determined by dry combustion method at $900^{\circ} \mathrm{C}$ using elemental CN analyzer (Vario Max Elementar, Germany). The SOC concentration was corrected for coal-C contribution by the methods developed by this project at C-MASC. Detailed procedures are described under sections 4.1 and 4.2 below. Soil bulk density was determined using core method (Grossman and Reinsch, 2002). Bulk density was used to convert concentration to SOC pools using equation (Eq 1)

$$
\left(\begin{array}{ll}
h & )=-\times \times \times
\end{array}\right.
$$

where $\rho_{b}$ is the bulk density $\left(\mathrm{Mg} \mathrm{m}^{-3}\right)$ of the soil depth corrected for coarse fragments, $d$ is the soil depth and SOC is soil organic carbon expressed as a weight based percentage.

\section{RESULTS AND DISCUSSION}

4.1 Task 1: Development of ${ }^{13} \mathrm{C}$-based procedure to determine the fraction of coal-C present in reclaimed soils

\subsubsection{Samples Pretreatment, Elemental and stable carbon isotope Analysis}

Samples were acid-washed to remove carbonates prior to $\delta^{13} \mathrm{C}$ analysis. Briefly, $5 \mathrm{~g}$ of finely ground $(<250 \mu \mathrm{m})$ soil was treated with $50 \mathrm{~mL}$ of $1 \mathrm{M} \mathrm{HCl}$ and the acid-soil mixture was allowed to react with frequent stirring for a 24-hr period. Soils were washed with deionized (DI) 
water 5 times, oven-dried at $60^{\circ} \mathrm{C}$ for $72 \mathrm{hrs}$ and fine-ground by mortar and pestle. Carbon and $\mathrm{N}$ concentrations of acid treated and untreated samples were determined by dry combustion method $\left(900^{\circ} \mathrm{C}\right)$ using an elemental analyzer (Vario Max, Elementar, Germany). The inorganic C concentration was obtained by subtracting $\mathrm{C}$ concentration of the acid treated sample from that of the untreated sample.

The $\delta^{13} \mathrm{C}$ of the acid treated soil samples were determined on $\mathrm{CO}_{2}$ produced by combustion of acid treated soils at $1020^{\circ} \mathrm{C}$ in oxygen using the elemental analyzer (Euro EA, EuroVector Instruments \& software, Milan, Italy) interfaced with stable isotope ratio mass spectrometer (IsoPrime, GV Instruments, Manchester, UK). The mass spectrometer was used for quantifying the ratio of ${ }^{13} \mathrm{C} /{ }^{12} \mathrm{C}$ in delta notation $\left(\delta^{13} \mathrm{C}\right)$. The instrument was acquired by the funding from this project. The isotopic signature is expressed in the delta notation $\left(\delta^{13} \mathrm{C}\right)$ relative to international standard PDB (Craig, 1957),

$$
\delta{ }^{13} C(\%)=\left[\frac{{ }^{13} C /{ }^{12} C_{\text {sample }}}{{ }^{13} C /{ }^{12} C_{\text {reference }}}-1\right] \times 1000
$$

where ${ }^{13} C /{ }^{12} C_{\text {sample }}$ is the stable isotope ratio of the sample and ${ }^{13} C /{ }^{12} C_{\text {reference }}$ is the stable isotope ratio of the PDB standard. The $\delta^{13} \mathrm{C}$ measurements are reproducible at $\pm 0.3 \%$.

The instrument was calibrated using the standard reference material (graphite) obtained from National Institute of Standards and Technology (NIST). These samples have a known isotopic composition referenced to Pee Dee Belemnite (PDB), a limestone fossil of Belemnitella americana from Cretaceous Pee Dee formation in South Carolina, which, as a basis of the PDB scale, it is assigned a $\delta^{13} \mathrm{C}$ of $0 \%$. These standards were used to calibrate the reference gas, and also internal laboratory standards to use in the day to day analyses. 


\subsubsection{Calculation of coal-C and recent $\mathrm{OC}$ fractions}

The fraction of $\mathrm{C}$ originating from coal was computed using isotope mixing model (Bernoux et al., 1998) as follows:

$$
F_{c}=\frac{\delta_{t}-\delta_{s}}{\delta_{c}-\delta_{s}}
$$

Eq 3

where $\delta_{\mathrm{t}}, \delta_{\mathrm{s}}$ and $\delta_{\mathrm{c}}$ refers to ${ }^{13} \mathrm{C}$ composition as $(\% o)$ of the mixture, soil and coal, respectively.

\subsubsection{Analysis of soil and coal mixtures of known composition}

Carbonate/bicarbonate-free and coal-free soil sample were collected from western Ohio agricultural site with no history of coal mining. Soil was air-dried, ground and sieved to pass 60 mesh ( $250 \mu \mathrm{m}$ sieve). Coal sample was obtained from the mining company in south east Ohio. Coal was crushed and then grounded by ball mill and sieved to pass 60 mesh ( $250 \mu \mathrm{m}$ sieve). Soil and coal mixtures were prepared as follows:

$\mathbf{S}_{\mathbf{0}}$ : untreated soil

$\mathbf{S}_{1}: 150 \mathrm{~g}$ soil $+0.5 \mathrm{~g}$ coal

$\mathbf{S}_{2}: 140 \mathrm{~g}$ soil $+1.5 \mathrm{~g}$ coal

$\mathbf{S}_{3}: 100 \mathrm{~g}$ soil $+3.5 \mathrm{~g}$ coal

$\mathbf{S}_{4}: 95 \mathrm{~g}$ soil $+5.0 \mathrm{~g}$ coal

S5: $99.63 \mathrm{~g}$ soil $1+0.37 \mathrm{~g}$ coal

S6: $98.72 \mathrm{~g}$ soil $+1.28 \mathrm{~g}$ coal

S7: $94.71 \mathrm{~g}$ soil $+5.29 \mathrm{~g}$ coal

Mixtures were analyzed for the $\delta^{13} \mathrm{C}$ composition. Coal and recent $\mathrm{OC}$ fractions were calculated. Table 1 shows an estimated coal-derived $\mathrm{C}$ in the soil and coal mixtures of different composition calculated based on the isotope mixed model approach (Bernoux et al 1998). The $\delta^{13} \mathrm{C}$ of coal- 
free soil samples were greater than that of coal samples. In addition, $\delta^{13} \mathrm{C}$ of soil and coal mixtures decreased with increase in quantity of coal added. The data indicates that the approach was very effective, and the calculated $\mathrm{C}$ concentrations were nearly the same as the measured changes in $\mathrm{C}$ concentration due to addition of coal in the mixture. These data suggests that the isotopic composition of the minesoils can be used to calculate the coal contribution in the minesoils, especially in minesoils where $\delta^{13} \mathrm{C}$ concentration (in per mil) of recent organic matter signal differ from that of the pure coal signal. The analysis of coal soil mixtures indicated that as the concentration of coal $\mathrm{C}$ increased, the $\delta^{13} \mathrm{C}$ concentration decreased. Recovery of coal, which is the ratio of calculated coal $\mathrm{C}$ and added coal $\mathrm{C}$ ranged from 93.9 to $102.0 \%$. The highest recovery was observed for mixtures with lower coal fractions.

Table 1. Calculated and actual coal-derived $C$ in soil coal mixtures computed based on the $\delta^{13} \mathrm{C}$ isotopic signature changes

\begin{tabular}{|c|c|c|c|c|c|c|c|}
\hline \multirow[t]{2}{*}{$\begin{array}{c}\text { Mixture } \\
\text { Composition }\end{array}$} & \multicolumn{3}{|c|}{ Organic $\mathrm{C}$ composition (\%) } & \multirow{2}{*}{$\begin{array}{c}\begin{array}{c}\delta^{13} \mathrm{C} \text { of } \\
\text { mixture }\end{array} \\
\delta^{13} \mathrm{C}(\% o)\end{array}$} & \multicolumn{3}{|c|}{$\begin{array}{l}\text { Total } \mathrm{C} \text { in mixture derived from coal } \\
\qquad(\%)\end{array}$} \\
\hline & SOC & Coal & Total & & Expected & Calculated & recovery \\
\hline Coal 1 & - & 64.3 & 64.3 & $-24.49 \pm 0.07$ & - & - & - \\
\hline Coal 2 & - & 59.4 & 59.4 & $-24.24 \pm 0.63$ & - & - & - \\
\hline Soil 1 & 1.72 & - & 1.72 & $-18.50 \pm 0.02$ & - & - & - \\
\hline Soil 2 & 2.57 & - & 2.57 & $-14.91 \pm 0.21$ & - & - & - \\
\hline $\begin{array}{l}\text { S1 }(150 \text { g soil }+0.5 \\
\text { g coal })\end{array}$ & 1.72 & 0.40 & 2.12 & $-19.89 \pm 0.08$ & 18.9 & 18.6 & 98.4 \\
\hline $\begin{array}{l}\mathrm{S} 2(140 \mathrm{~g} \text { soil }+1.5 \\
\mathrm{g} \text { coal })\end{array}$ & 1.72 & 1.15 & 2.87 & $-21.35 \pm 0.02$ & 40.1 & 40.9 & 102.0 \\
\hline $\begin{array}{l}\text { S3 }(100 \text { g soil }+3.5 \\
\text { g coal })\end{array}$ & 1.72 & 2.21 & 3.93 & $-22.76 \pm 0.05$ & 56.2 & 54.4 & 96.8 \\
\hline 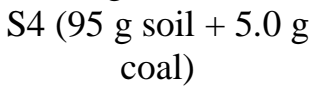 & 1.72 & 3.21 & 4.93 & $-23.17 \pm 0.02$ & 65.3 & 61.3 & 93.9 \\
\hline $\begin{array}{c}\text { S5 }(99.63 \mathrm{~g} \text { soil } 1+ \\
0.37 \mathrm{~g}\end{array}$ & 1.72 & 0.64 & 2.36 & $-19.89 \pm 0.26$ & 27.1 & 26.4 & 97.4 \\
\hline $\begin{array}{l}\text { S6 }(98.72 \mathrm{~g} \text { soil } 2+ \\
1.28 \mathrm{~g} \text { coal } 2)\end{array}$ & 2.57 & 0.76 & 3.33 & $-17.45 \pm 0.12$ & 22.8 & 22.3 & 97.8 \\
\hline $\begin{array}{l}\text { S7 }(94.71 \mathrm{~g} \text { soil } 2+ \\
\quad 5.29 \mathrm{~g} \text { coal } 2)\end{array}$ & 2.57 & 3.14 & 5.71 & $-20.45 \pm 0.09$ & 55.0 & 51.8 & 94.2 \\
\hline
\end{tabular}


The major limitation of this approach is the wide range of isotopic signature of C3 plants commonly occurring in post-reclamation land-uses which overlaps isotope signature of coal, rendering this approach unreliable for soils dominated by $\mathrm{C} 3$ plants. This approach, can produce reliable estimates of coal $\mathrm{C}$ fraction in soils where post-reclamation land-use is long-term corn or other C4 plants.

\subsubsection{Isotopic composition of coal, plant biomass and soils}

The isotopic composition of coal samples collected from the experimental sites in eastern Ohio ranged from -25.123 to $-23.980 \%$ o $(n=7$, mean $=-24.537 \%$, standard deviation $\pm 0.25 \%$ o $)$. The composition of plant samples obtained from grazing sites (forage plants) ranged from -29.185 to $-26.592 \%$ o $(\mathrm{n}=15$, mean $=-27.841 \%$ o standard deviation $\pm 0.909 \%$ $)$, and the composition of the forest litter collected from reclaimed forest ranged from -26.984 to 28.645\%o (mean -28.006\%o, standard deviation $\pm 0.891 \%$ ). Mean and ranges observed in this experiment are within the stable isotope composition ranges reported in other studies for the $\mathrm{C}_{3}$ plants. In general, the variability of $\delta^{13} \mathrm{C}$ was small in coal and larger in plant samples.

Table 2. Stable isotope composition of coal and plant litter (mean \pm standard error).

\begin{tabular}{lc}
\hline Source & $\delta^{13} \mathrm{C}(\% \circ)$ \\
\hline Coal & $-24.537 \pm 0.113$ \\
Grass & $-27.841 \pm 0.244$ \\
Forest litter & $-28.510 \pm 0.190$ \\
\hline
\end{tabular}

Stable isotope analysis of soil samples is presented in Table 5. The $\delta^{13} \mathrm{C}$ for analyzed minesoils ranged from -26.98 to $-17.20 \%$ and increased with increase in soil depth. Increase in $\delta^{13} \mathrm{C}$ with increase in soil depth has been associated with increase in organic matter decomposition with depth, due to microbial discrimination of heavier ${ }^{13} \mathrm{C}$ isotope. The coal $\mathrm{C}$ concentration estimated 
by isotopes mixed model calculation and recent $\mathrm{C}$ concentration ranged from 1.8 to 10 , and 1.3 to $69.7 \mathrm{~g} \mathrm{~kg}^{-1}$, respectively. Coal $\mathrm{C}$ accounted for 12 to $86 \%$ of SOC in these soils. Generally, coal-derived C was the major SOC fraction in the sub-soil (20-50 cm depth), accounting for more than $50 \%$ of SOC concentration by isotope calculation in all sites evaluated.

Table 3. Concentration of coal, and recent OC estimated by isotope mixed model in the RMS (mean \pm standard deviation).

\begin{tabular}{|c|c|c|c|c|}
\hline Depth & $\delta^{13} \mathrm{C}$ & Coal C & Recent OC & Coal C/TOC \\
\hline & $(\% o)$ & \multicolumn{2}{|c|}{------------g C/kg of soil------------ } & $\%$ \\
\hline \multicolumn{5}{|c|}{ East Cumberland (meadow) } \\
\hline $0-5$ & $-25.28 \pm 0.29$ & $4.6 \pm 1.6$ & $31.5 \pm 1.7$ & 13 \\
\hline $5-10$ & $-24.84 \pm 0.01$ & $3.5 \pm 0.6$ & $15.5 \pm 0.1$ & 18 \\
\hline $10-20$ & $-23.73 \pm 0.55$ & $3.0 \pm 0.6$ & $6.5 \pm 0.8$ & 32 \\
\hline $20-30$ & $-25.03 \pm 1.64$ & $1.8 \pm 2.3$ & $4.4 \pm 2.3$ & 29 \\
\hline $30-40$ & $-23.74 \pm 1.48$ & $2.7 \pm 2.0$ & $3.5 \pm 1.8$ & 44 \\
\hline $40-50$ & $-24.16 \pm 0.03$ & $3.7 \pm 0.5$ & $2.1 \pm 0.0$ & 64 \\
\hline \multicolumn{5}{|c|}{ High Hill (Grazing) } \\
\hline $0-5$ & $-26.98 \pm 1.28$ & $5.2 \pm 31.8$ & $68.0 \pm 47.3$ & 7 \\
\hline $5-10$ & $-26.84 \pm 0.58$ & $4.0 \pm 17.8$ & $8.3 \pm 20.2$ & 32 \\
\hline $10-20$ & $-25.74 \pm 0.91$ & $7.9 \pm 2.7$ & $8.6 \pm 5.2$ & 48 \\
\hline $20-30$ & $-24.45 \pm 0.44$ & $10.0 \pm 8.0$ & $4.9 \pm 0.8$ & 67 \\
\hline $30-40$ & $-24.60 \pm 1.04$ & $5.9 \pm 11.9$ & $4.8 \pm 1.5$ & 55 \\
\hline $40-50$ & $-25.05 \pm 1.03$ & $6.1 \pm 14.3$ & $1.0 \pm 1.3$ & 86 \\
\hline \multicolumn{5}{|c|}{ Mount Carmel (hardwood forest) } \\
\hline $0-5$ & $-27.31 \pm 0.52$ & $6.5 \pm 5.4$ & $69.7 \pm 6.8$ & 9 \\
\hline $5-10$ & $-26.85 \pm 0.43$ & $4.0 \pm 1.9$ & $8.8 \pm 6.4$ & 31 \\
\hline $10-20$ & $-25.79 \pm 0.47$ & $3.5 \pm 0.7$ & $3.3 \pm 1.1$ & 52 \\
\hline $20-30$ & $-25.07 \pm 0.36$ & $3.8 \pm 0.4$ & $2.5 \pm 0.7$ & 71 \\
\hline $30-40$ & $-24.63 \pm 0.39$ & $3.7 \pm 0.9$ & $3.8 \pm 0.6$ & 49 \\
\hline $40-50$ & $-24.88 \pm 0.66$ & $4.1 \pm 0.9$ & $3.9 \pm 0.6$ & 51 \\
\hline \multicolumn{5}{|c|}{ Mount Carmel (grazing) } \\
\hline $0-5$ & $-25.03 \pm 0.76$ & $6.5 \pm 57.4$ & $25.8 \pm 10.3$ & 20 \\
\hline $5-10$ & $-24.77 \pm 0.76$ & $5.9 \pm 45.1$ & $12.3 \pm 12.5$ & 32 \\
\hline $10-20$ & $-24.19 \pm 0.94$ & $6.3 \pm 3.3$ & $6.3 \pm 2.2$ & 50 \\
\hline $20-30$ & $-23.03 \pm 1.98$ & $6.7 \pm 4.1$ & $1.5 \pm 2.9$ & 82 \\
\hline $30-40$ & $-21.46 \pm 1.08$ & $8.3 \pm 3.0$ & $3.2 \pm 1.9$ & 72 \\
\hline $40-50$ & $-21.24 \pm 1.15$ & $8.5 \pm 0.8$ & $3.6 \pm 0.4$ & 70 \\
\hline \multicolumn{5}{|c|}{ Tiltons' Run (meadow) } \\
\hline $0-5$ & $-25.44 \pm 0.38$ & $3.1 \pm 1.0$ & $14.6 \pm 2.0$ & 18 \\
\hline $5-10$ & $-24.47 \pm 1.36$ & $5.1 \pm 0.5$ & $10.0 \pm 1.9$ & 35 \\
\hline $10-20$ & $-23.83 \pm 0.60$ & $7.4 \pm 0.7$ & $1.3 \pm 0.4$ & 85 \\
\hline $20-40$ & $-17.20 \pm 8.06$ & $6.1 \pm 4.4$ & $1.7 \pm 2.5$ & 79 \\
\hline
\end{tabular}




\subsection{Task 2: Development of Chemi-thermal procedure to quantify coal-derived C and newly}

\section{deposited C fractions in RMS}

\subsubsection{Chemi-thermal method development}

A method for quantification of coal $\mathrm{C}$ based on its resistance to chemical extraction and thermal oxidation was developed. The method involves pre-treatments to remove SIC and recent SOC fractions. Coal $\mathrm{C}$ is quantified by an elemental $\mathrm{C}$ analysis of the residual soil sample. The summary of procedure in schematic flow diagram is presented in Fig. 1. The detailed procedure is as follows:

Two grams of dry and finely ground soil samples $(250 \mu \mathrm{m})$ were placed in a centrifuge tubes and treated with $20 \mathrm{~mL}$ of $1 \mathrm{M} \mathrm{HCl}$. Samples were allowed to react for 30 minutes with intermittent shaking, centrifuged for $20 \mathrm{~min}(3000 \mathrm{G})$, supernatant was decanted and discarded. This step was repeated twice, with continuous shaking followed by centrifuging and decanting of the supernatant. The acid treatment removed all carbonate (inorganic) C. Residual acid was neutralized by addition of $20 \mathrm{~mL}$ of $0.5 \mathrm{M} \mathrm{NaOH}$, shaking for $1 \mathrm{hr}$ and centrifuging. Recent SOC was extracted with $0.5 \mathrm{M} \mathrm{NaOH}$ at 1:10 soil weight to extractant volume ratio. Samples were shaken on mechanical shaker for $15 \mathrm{hrs,} \mathrm{centrifuged} \mathrm{and} \mathrm{supernatant} \mathrm{was} \mathrm{discarded.} \mathrm{Extraction}$ was repeated 2 times with 1 hour shaking each. Residual soil was rinsed twice with DI water to remove released $\mathrm{SOM}$ and excess $\mathrm{NaOH}$. Twenty $\mathrm{mL}$ of $60 \% \mathrm{HNO}_{3}$ was added and shaken for 15 minutes. Samples were centrifuged and supernatant was discarded. 
Treatment

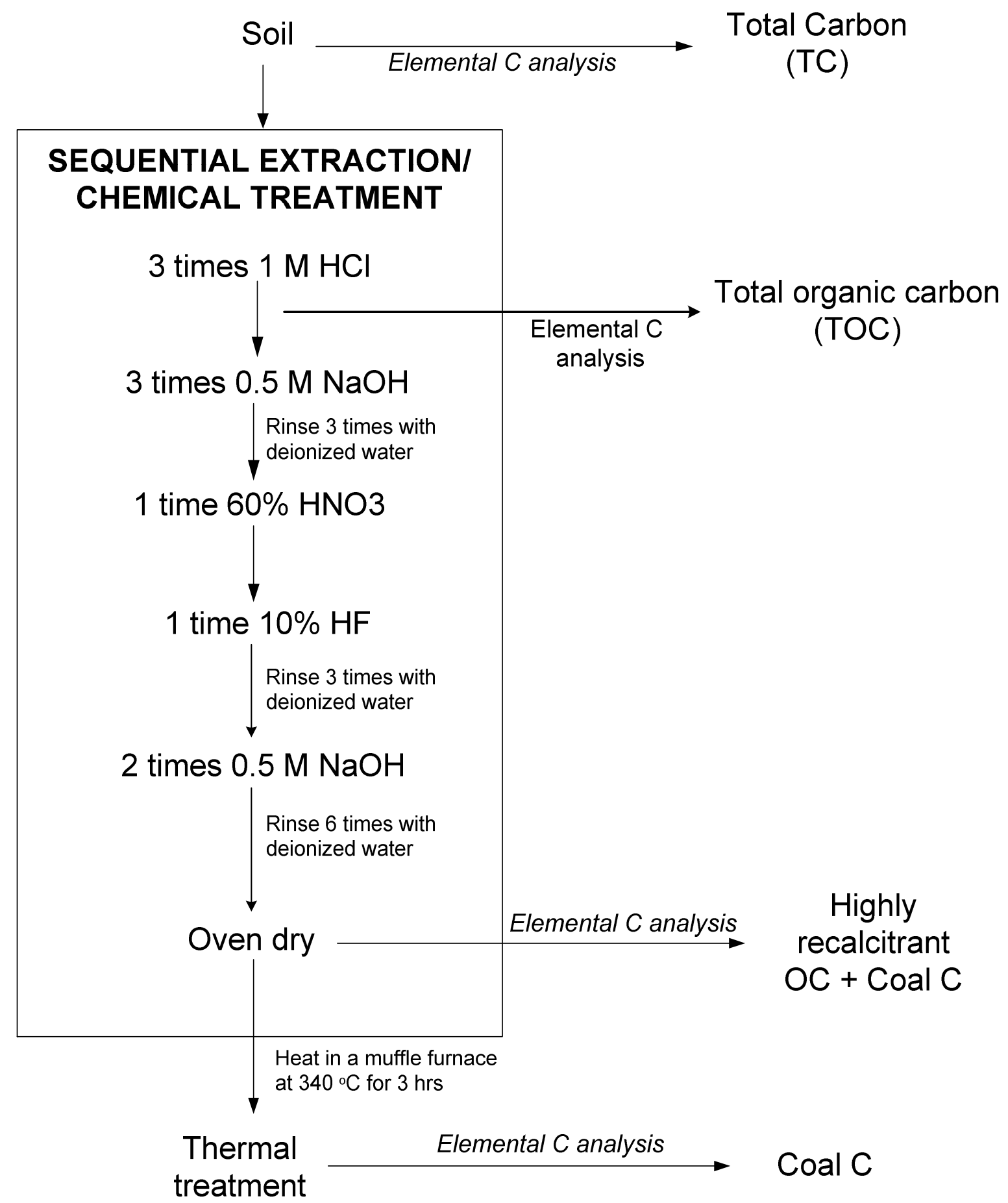

Figure 1. Summary of the steps and processes for removing recent organic carbon for coal-derived C quantification in RMS. 
To the residual soil, $20 \mathrm{~mL}$ of $10 \% \mathrm{HF}$ was added and allowed to react for 4 hrs with intermittent stirring. The HF treatment demineralizes the sample and release mineral bound OM. Samples were centrifuged and again extracted twice with $20 \mathrm{~mL}$ of $0.5 \mathrm{M} \mathrm{NaOH}$ for $30 \mathrm{~min}$ each. Residual soils were rinsed with DI water 6 times to remove all $\mathrm{NaOH}$, oven dried at $60^{\circ} \mathrm{C}$ for $48 \mathrm{hrs}$ and ground. These steps removed all inorganic $\mathrm{C}$ and most of the recent SOC.

To remove highly recalcitrant SOC (i.e. humin), $1 \mathrm{~g}$ of the extracted sample was weighed into crucible and placed in a muffle furnace at $340 \pm 5^{\circ} \mathrm{C}$ for $3 \mathrm{hrs}$. Thermal oxidation step removed recalcitrant $\mathrm{C}$, which was resistant to $\mathrm{NaOH}$ extraction. The remaining $\mathrm{C}$ that was resistant to chemical extraction and thermal oxidation is defined as coal C. This was quantified by dry combustion method using an elemental $\mathrm{CN}$ analyzer.

\subsubsection{Chemi-thermal treatment of soil and coal mixtures}

Chemical extraction and thermal oxidation had little effect on coal C (Table 4). Mass balance indicated that about $99.7 \%$ of coal $\mathrm{C}$ was recovered after chemi-thermal treatment. This observation suggested that coal samples tested was resistant to chemical treatments and low temperature oxidation applied in this method. Chemi-thermal treatment of coal-free soils indicated that $9.3 \%$ of SOC remained non-extracted (Table 4). The amount of OC removed from the mixtures ranged from 87 to $99 \%$ of recent SOC (Table 4). The effectiveness of the treatment decreased with increasing coal $\mathrm{C}$ in the mixture $\left(\mathrm{r}^{2}=0.66, \mathrm{P} \leq 0.05\right)$. Chemi-thermal treated artificial mixtures of soil and coal were more depleted in stable ${ }^{13} \mathrm{C}$ isotope than the untreated samples (Table 4). This suggests that chemi-thermal treatment removed mainly recent SOC, which was enriched in $\delta^{13} \mathrm{C}$. This is supported by the fact that $\delta^{13} \mathrm{C}$ of post-treatment mixtures falls within the isotopic range of the coal sample. 
Table 4. Estimated coal $\mathrm{C}$ concentration based on $\delta^{13} \mathrm{C}$ isotopic signature changes after chemi-thermal treatment to remove recent organic matter.

\begin{tabular}{ccccccc}
\hline Sample & \multicolumn{3}{c}{$\begin{array}{c}\text { Total organic C of the } \\
\text { sample (\%) }\end{array}$} & \multicolumn{2}{c}{ Recovery (\%) } & \multicolumn{2}{c}{$\begin{array}{c}\text { Isotopic composition of the } \\
\text { sample }\end{array}$} \\
& Before & after & expected & observed & Before & after \\
\hline Coal & 64.3 & 64.1 & 100 & 99.7 & $-24.49 \pm 0.07$ & $-24.47 \pm 0.04$ \\
Soil S0 & 1.72 & 0.16 & 0.0 & 9.3 & $-18.50 \pm 0.02$ & $-23.69 \pm 0.05$ \\
\hline Soil-coal mixtures & & & & & & \\
S1 & 2.12 & 0.52 & 18.9 & 24.5 & $-19.89 \pm 0.08$ & $-25.52 \pm 0.08$ \\
S2 & 2.87 & 1.16 & 40.1 & 40.4 & $-21.35 \pm 0.02$ & $-25.47 \pm 0.10$ \\
S3 & 3.93 & 2.28 & 54.4 & 58.0 & $-22.76 \pm 0.05$ & $-25.52 \pm 0.09$ \\
S4 & 4.93 & 3.71 & 61.3 & 55.0 & $-23.17 \pm 0.02$ & $-24.68 \pm 0.05$ \\
S5 & 2.36 & 0.8 & 27.1 & 33.9 & $-21.35 \pm 0.15$ & -25.52 \\
S6 & 3.33 & 0.89 & 22.8 & 26.7 & $-17.45 \pm 0.12$ & -23.52 \\
S7 & 5.71 & 3.39 & 55.0 & 59.4 & $-20.45 \pm 0.09$ & -23.03 \\
\hline
\end{tabular}

\subsubsection{Chemi-thermal treatment of reclaimed minesoils}

Coal $\mathrm{C}$ concentration of the RMS determined by chemi-thermal method ranged from 1.5 to $25.4 \mathrm{~g} \mathrm{~kg}^{-1}$ of soil (Table 5). Coal C concentration was higher in the subsoil (30-50 $\mathrm{cm} \mathrm{depth)}$ than in the surface layers $(0-10 \mathrm{~cm}$, Table 5). Except samples from top $10 \mathrm{~cm}$ depth, all other post- treatment minesoil samples were enriched $\delta^{13} \mathrm{C}$ compared to pre-treated samples, and posttreatment $\delta^{13} \mathrm{C}$ fell within the range of coal (Tables 2, 5), suggesting that the residual $\mathrm{C}$ in the treated samples is dominated by coal $\mathrm{C}$ fraction. Radiocarbon analysis indicated that two samples from the top 0-5 and 5-10 cm depths are coal-free, with radiocarbon age >modern (i.e., ${ }^{14} \mathrm{C}$ activity of the sample is greater than $95 \%$ of measured net standard oxalic acid ${ }^{14} \mathrm{C}$ activity (Table 6; Stuiver and Polach., 1977), however, chemi-thermal method detected 3.3 and 7.9\% residual OC (Table 5) in these samples. Stable isotope composition of the residual OC of these samples did not differ from the untreated sample, and remained within the ranges of OM of plant origin, indicating that residual $\mathrm{OC}$ of the top $0-10 \mathrm{~cm}$ depth at this site is of recent $\mathrm{OM}$ origin (Table 5). Chemical extraction of recent OM from mineral soils is controlled by multiple factors including reaction conditions such as $\mathrm{pH}$ and temperature; and soil properties, namely 
mineralogy, OM concentration and quality (Mikutta et al., 2005). Studies involving black C determination in soils have indicated that chemical oxidative techniques are not able to completely remove OM from soils (Schmidt and Noack, 2000; Schmidt et al., 2001; Simpson and Hatcher, 2004) due to OM stabilization by association with mineral matrix and highly recalcitrant nature of a small fraction of SOM. In this procedure, demineralization using HF treatment liberates mineral protected OC and makes it accessible to thermal treatment, thereby increasing the efficiency of themi-thermal treatment. Several studies have indicated that aliphatic C makes a large portion of highly recalcitrant OM resistant to oxidation treatments (Righi et al., 1995; Schulten et al., 1996; Cuypers et al., 2002).

Table 5. Effects of chemi-thermal treatment, on total organic carbon of the reclaimed minesoils.

\begin{tabular}{ccccccc}
\hline Sample & $\begin{array}{c}\text { Soil depth } \\
(\mathrm{cm})\end{array}$ & $\begin{array}{c}\text { Total organic } \\
\mathrm{C}\left(\mathrm{g} \mathrm{kg}^{-1}\right)\end{array}$ & \multicolumn{2}{c}{ Residual (coal) $\mathrm{C}\left(\mathrm{g} \mathrm{kg}^{-1}\right)$} & \multicolumn{2}{c}{$\delta^{13} \mathrm{C}(\% o)$} \\
& & & Expected & Measured & before & after \\
\hline Mt Carmel Hay & $30-40$ & 27.9 & 24.4 & 25.4 & -25.08 & -24.51 \\
Mt Carmel pasture & $40-50$ & 18.9 & 16.5 & 14.7 & -24.30 & -24.61 \\
Mt Carmel pasture & $0-5$ & 155.8 & 0 & 5.1 & -26.56 & -26.56 \\
Mt Carmel pasture & $5-10$ & 18.9 & 0 & 1.5 & -26.64 & -26.55 \\
Mt Carmel pasture & $10-20$ & 3.6 & 0.4 & 0.7 & -25.85 & -24.84 \\
Mt Carmel pasture & $20-30$ & 11.4 & 8.6 & 9.1 & -25.02 & -24.73 \\
High Hill pasture & $20-30$ & 23.2 & 8.7 & 8.9 & -25.17 & -25.02 \\
Mt Carmel pasture & $30-40$ & 15.7 & 14.4 & 13.8 & -23.83 & -24.81 \\
\hline
\end{tabular}

Generally, reclamation techniques employed influence the distribution of coal C in RMS. Minesoils from the sites reclaimed with topsoil application tend to have an upper 10 to $20 \mathrm{~cm}$ soil depth with very low or no coal contamination. This was observed for summit, shoulder and foot slope sampling locations (Table 5; data for summit and foot slope not shown). Overall, coal C contributed 3.3 to $91.2 \%$ of TOC in the RMS in these sites. Thus, coal C was the dominant 
fraction of TOC in the subsoil (30-50 cm depth), accounting for more than 70\% of TOC in RMS. This can be attributed to dominance of spoil in the subsoil. Overall, spoils contain higher coal C fraction than the topsoil.

\subsection{Task 3: Cross-validation of 13C-based and chemi-thermal procedures to assess coal-C fraction in RMS.}

\subsubsection{Radiocarbon Activity Measurement}

The ${ }^{14} \mathrm{C}$ activity of soil was measured at Woods Hole Oceanographic Institution (WHOI) using accelerator mass spectroscopy (AMS). Due to high analytical costs, a limited number of minesoil samples and soil and coal mixtures were analyzed for radiocarbon activity. Sample pretreatment included acid-washing to remove inorganic $\mathrm{C}$, drying and fine grounding and sieving through $250-\mu \mathrm{m}$ sieve. For this analysis, soil sample containing $250-500 \mu \mathrm{g}$ of $\mathrm{C}$ were ignited at $900^{\circ} \mathrm{C}$ to produce $\mathrm{CO}_{2}$. The $\mathrm{CO}_{2}$ produced was reduced to graphite by $\mathrm{H}_{2}$ over an iron catalyst at $600^{\circ} \mathrm{C}$. The graphite was pressed into a target holder and analyzed using AMS. Oxalic acid (National Institute of Standards and Technology (NIST) standard reference material (SRM) 4990 $-\delta^{13} \mathrm{C}=-19.0 \%$ ) and graphite were used as standard and process blanks, respectively. Blanks were used for correction of ${ }^{14} \mathrm{C}$ from contamination introduced during chemical preparation, collection and handling of the samples. Radiocarbon activity measurements are reported as $\Delta{ }^{14} \mathrm{C}$ (per mil). The ${ }^{14} \mathrm{C}$ activity was corrected for ${ }^{13} \mathrm{C}$ isotopic fractionation as described by (Stuiver and Polach, 1977).

\subsubsection{Calculation of SOM Age and Radiocarbon Activity}

Coal in the Appalachian region was formed during Pennsylvanian and Permian periods about 245 to 320 million years ago (Crowell, 2002) and free of ${ }^{14} \mathrm{C}$ activity (i.e. "dead carbon”) 
due to ${ }^{14} \mathrm{C}$ half-life of 5730 years (Rumpel $1998 ; 2000$ ). The ${ }^{14} \mathrm{C}$ activity of the atmospheric $\mathrm{CO}_{2}$ has not been stable over the past 50 yrs (Manning et al., 1990). In the late 50 s to early $1960 \mathrm{~s},{ }^{14} \mathrm{C}$ activity of the atmospheric $\mathrm{CO}_{2}$ increased dramatically due to nuclear bomb testing, and it has been decreasing progressively since (Rafter and Stout, 1970). The ${ }^{14} \mathrm{C}$ activity of plant materials after correction for isotopic fractionation has been the same as the atmospheric ${ }^{14} \mathrm{CO}_{2}$, which the plant acquired during photosynthesis and incorporated in their tissue. Recent SOM in the RMS is a mixture of OM of different age, which accumulated during minesoil development. Due to changes in of atmospheric ${ }^{14} \mathrm{CO}_{2}$, the ${ }^{14} \mathrm{C}$ content of recent SOM depends on the period when ${ }^{14} \mathrm{CO}_{2}$ was assimilated by the stand and entered into the soil. Therefore, the ${ }^{14} \mathrm{C}$ activity of recent SOM is a function of a mean age of respective organic material, which may differ with soil depth and influenced by stand variability.

The ${ }^{14} \mathrm{C}$ activities of process blank, standard and samples were used for the calculation of the fraction modern $(\mathrm{Fm})$ from this expression:

$$
F m=\frac{\Delta^{14} C_{\text {sample }}-\Delta^{14} C_{\text {blank }}}{\Delta^{14} C_{\text {standard }}-\Delta^{14} C_{\text {blank }}}
$$

Fm is a measurement of the deviation of the ${ }^{14} \mathrm{C} /{ }^{12} \mathrm{C}$ ratio of a sample from "modern",,$\Delta{ }^{14} \mathrm{C}_{\text {sample }}$, $\Delta^{14} \mathrm{C}_{\text {blank }}$ and $\Delta{ }^{14} \mathrm{C}_{\text {standard }}$ represent the ${ }^{14} \mathrm{C} /{ }^{12} \mathrm{C}$ ratios of the sample, blank and standard (the modern reference), respectively. Modern is defined as $95 \%$ of the radiocarbon activity in A.D 1950 of the Oxalic acid (NIST RSM-4990) normalized to $\delta^{13} \mathrm{C}_{\mathrm{VPDB}}=-19 \%$ with respect to PDB (Olsson, 1970 ; Stuiver and Polach, 1977).

Radiocarbon age of the sample was calculated from Fm fraction by the expression $\operatorname{Age}(B P)=8033 \ln (F m)$ Eq 5

The conventional ${ }^{14} \mathrm{C}$ age is reported in years before present (BP), which means years before AD 
1950, because the activity of the oxalic acid standard reference is defined for this year.

Recent SOC and coal C concentrations of the sample were calculated from Fm and TOC as

Recent $S O C=F m \times T O C \quad$ Eq 6

Coal $C=(1-F m) T O C$

where TOC is total organic C concentration of the sample $\left(\mathrm{g} \mathrm{kg}^{-1}\right)$.

\subsubsection{Coal $\mathrm{C}$ and recent $\mathrm{OC}$ fractions of the soil and coal mixtures}

Analysis of soil and artificial mixtures of coal and soil indicated that recent SOC in the soil was modern, and the mixtures of coal and this soil produced an average ${ }^{14} \mathrm{C}$ age of 1380 and $5880 \mathrm{yr}$ before present (BP) for 22.8 and $60.2 \%$ coal C, respectively (Table 6). For the mixtures S6 and $\mathrm{S} 7$ an increase in average ${ }^{14} \mathrm{C}$ age was proportional to increase in coal $\mathrm{C}$ concentration. Coal $\mathrm{C}$ concentrations recovered by ${ }^{14} \mathrm{C}$ activity analysis accounted for 80 and $95 \%$ of added coal $\mathrm{C}$ in the artificial mixtures of soil and coal containing 22.8 and 55\% of TOC as coal C, respectively (Tables 1,6$)$. These results, although limited, indicates that both radiocarbon age and ${ }^{14} \mathrm{C}$ activity may be useful for determining contribution of dead carbon derived from coal in the minesoils.

Table 6. Radiocarbon age, vegetation- and coal-derived carbon contribution to total organic carbon in the RMS (numbers in brackets are standard errors).

\begin{tabular}{llccc}
\hline Site/land use & $\begin{array}{l}\text { Soil depth } \\
(\mathrm{cm})\end{array}$ & $\begin{array}{c}{ }^{14} \mathrm{C} \text { age } \\
(\text { yrs B.P. })\end{array}$ & $\begin{array}{c}\text { Recent OC } \\
\left(\mathrm{g} \mathrm{kg}^{-1}\right)^{\dagger}\end{array}$ & $\begin{array}{c}\text { Coal C } \\
\left(\mathrm{g} \mathrm{kg}^{-1}\right)\end{array}$ \\
\hline Coal-free soil & - & Modern & 25.7 & - \\
Soil-coal mixture S6 & - & $1380(30)$ & 25.7 & 6.1 \\
Soil-coal mixture S7 & - & $5880(45)$ & 25.7 & 29.7 \\
Mt Carmel Hay & $30-40$ & $16650(85)$ & $3.5(0.005)$ & 24.4 \\
Mt Carmel pasture & $40-50$ & $16650(65)$ & $2.8(0.003)$ & 16.5 \\
Mt Carmel pasture & $0-5$ & Modern & $155.8(0.1)$ & 0 \\
Mt Carmel pasture & $5-10$ & Modern & $19.5(0.1)$ & 0 \\
Mt Carmel pasture & $10-20$ & $1030(25)$ & $3.2(0.01)$ & 0.4 \\
Mt Carmel pasture & $20-30$ & $11200(55)$ & $2.8(0.005)$ & 8.6 \\
High Hill pasture & $20-30$ & $3790(45)$ & $14.5(0.05)$ & 8.7 \\
Mt Carmel pasture & $30-40$ & $20800(120)$ & $1.2(0.001)$ & 14.6 \\
\hline
\end{tabular}

$\dagger$ B.P. $=$ before present 


\subsubsection{Coal $\mathrm{C}$ and recent $\mathrm{OC}$ fractions of the RMS}

Coal $\mathrm{C}$ concentration of the minesoils calculated by ${ }^{14} \mathrm{C}$ activity is presented in Table 6. Coal $\mathrm{C}$ accounted for 0 to $92 \%$ of TOC in the RMS (Table 6). As expected, no coal $\mathrm{C}$ was detected in the top $10 \mathrm{~cm}$ depth (Table 6), indicating that all of the TOC in the top $10 \mathrm{~cm}$ originated from recent plant materials. The top $10 \mathrm{~cm}$ soils of this site developed from the applied topsoil, which was scrapped off and stored prior to mining, thereby minimizing chances for coal contamination. In the $10-20 \mathrm{~cm}$, however, about $12.5 \%$ of the TOC was from coal (Table 6). In the 20 to $30 \mathrm{~cm}$ depth, coal $\mathrm{C}$ accounted for 38 and $75 \%$ of the TOC for summit and shoulder, respectively. In the $30-50 \mathrm{~cm}$ depth, coal C ranged from 87 to $92 \%$ of TOC. Soil OC contribution of less than $100 \%$ as observed in the soil depths below $10 \mathrm{~cm}$ indicate that OC derived from plant litter and from coal are mixed in the lower soil depths.

For the minesoils analyzed, recent SOC concentration decreased while coal C concentration increased with increase in soil depth. In addition, coal $\mathrm{C}$ concentration in the mineral horizons varied with elevation positions. These variations are the result of the reclamation technique used in this site. Ohio Mining and Reclamation Act of 1972, and Federal Surface Mining and Reclamation Act (SMRA) of 1977 mandated the application of topsoil or suitable media for plant growth of about $30 \mathrm{~cm}$ on top of the spoil material. The topsoil which was scraped off before mining and is generally free of coal contamination, and contains low OC due to mineralization and leaching losses during storage, while the OC in spoil is exclusively coal. Spatial and depth variations in coal $\mathrm{C}$ concentration observed in this site could be due to physiographic variations and uneven surface created during grading. Coal $\mathrm{C}$ as a fraction of total $\mathrm{C}$ and $\delta^{13} \mathrm{C}$ of the minesoils SOM were strongly correlated $\left(\mathrm{r}^{2}=0.84 ; \mathrm{P}<0.01\right)$. High correlation between coal C fraction and $\delta^{13} \mathrm{C}$ indicated that presence of coal $\mathrm{C}$ fraction influenced the stable isotope composition of SOM. However, the slope and intercept of this relationship may vary depending 
on site-specific factors that govern the values of the end-members.

\subsubsection{Comparison of stable $C$ isotope ratio, chemi-thermal and radiocarbon analysis approaches.}

Relationship between coal-derived $\mathrm{C}$ determined by isotope calculation and chemi-thermal analysis for soil and coal mixtures is presented in Figure 2. Coal-C fraction calculated by $\delta 13 \mathrm{C}$ values and that estimated by chemi-thermal method were highly correlated $\left(\mathrm{R}^{2}=0.96, P<0.001\right.$; Fig. 2).

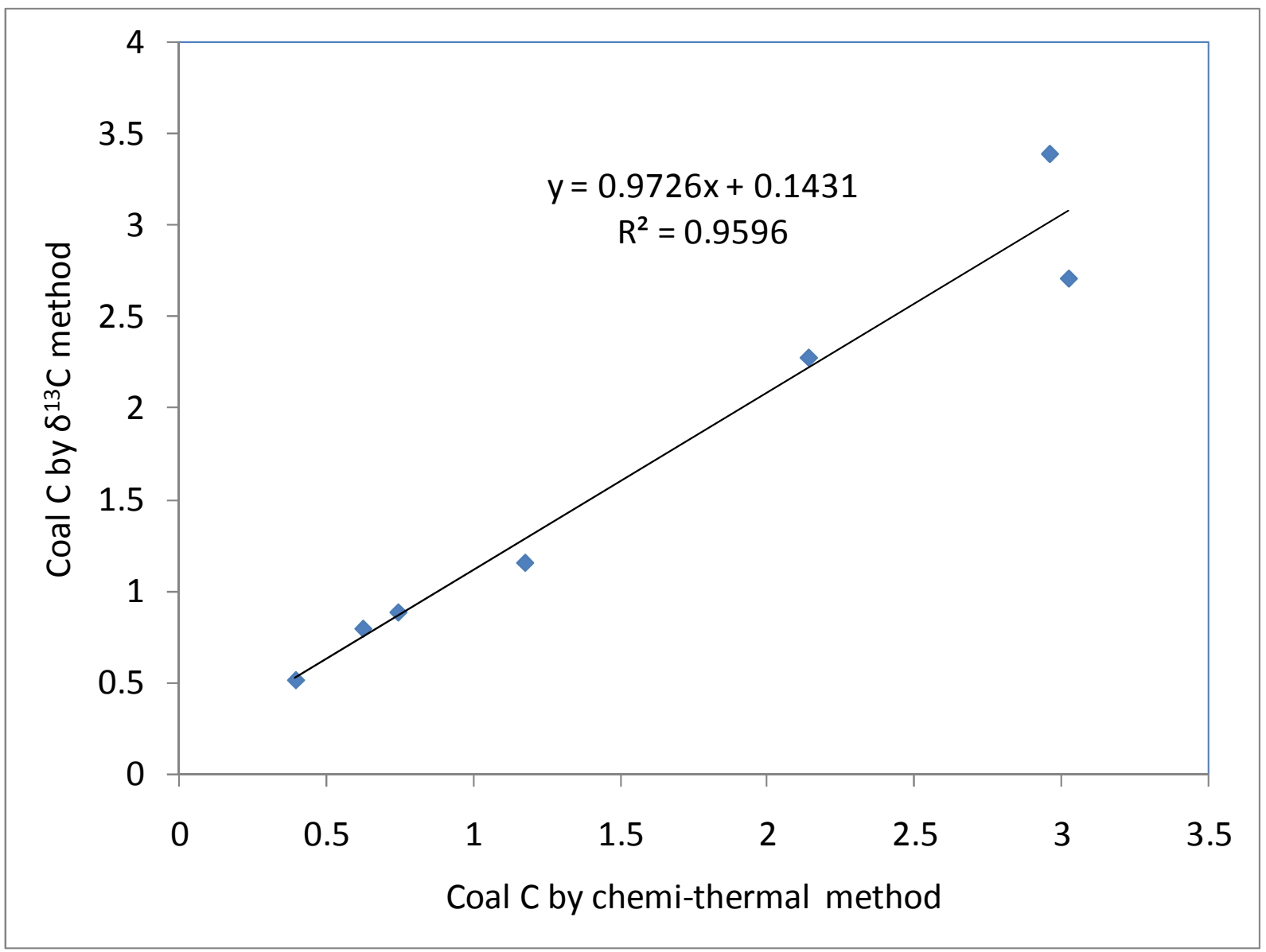

Figure 2. Relationship between coal-C fractions of soil-coal mixtures determined by $\delta^{13} \mathrm{C}$ and chemi-thermal methods 
The data suggests that about $96 \%$ of coal-C fraction determined by chemi-thermal technique can be explained by the variation in isotope signature, especially at sites were post-reclamation land use included a C4 plants.

\subsubsection{Relationship Between ${ }^{14} \mathrm{C}$ Activity Analysis and Chemi-thermal Method}

Comparison of coal $\mathrm{C}$ concentrations obtained by chemi-thermal analysis and ${ }^{14} \mathrm{C}$ activity analysis indicated that chemi-thermal treatment was as effective as radiocarbon analysis in quantifying coal $\mathrm{C}$ in this site. Coal $\mathrm{C}$ calculated by ${ }^{14} \mathrm{C}$ activity and chemi-thermal analysis were highly correlated (Fig. $2, \mathrm{r}^{2}=0.95$ ), suggesting that about $95 \%$ of residual OC determined by chemi-thermal method can be explained by ${ }^{14} \mathrm{C}$ activity. High correlation of coal $\mathrm{C}$ determined by two methods suggests that chemi-thermal method could be as effective as radiocarbon analysis in predicting coal $\mathrm{C}$ concentration in the coal-contaminated minesoils.

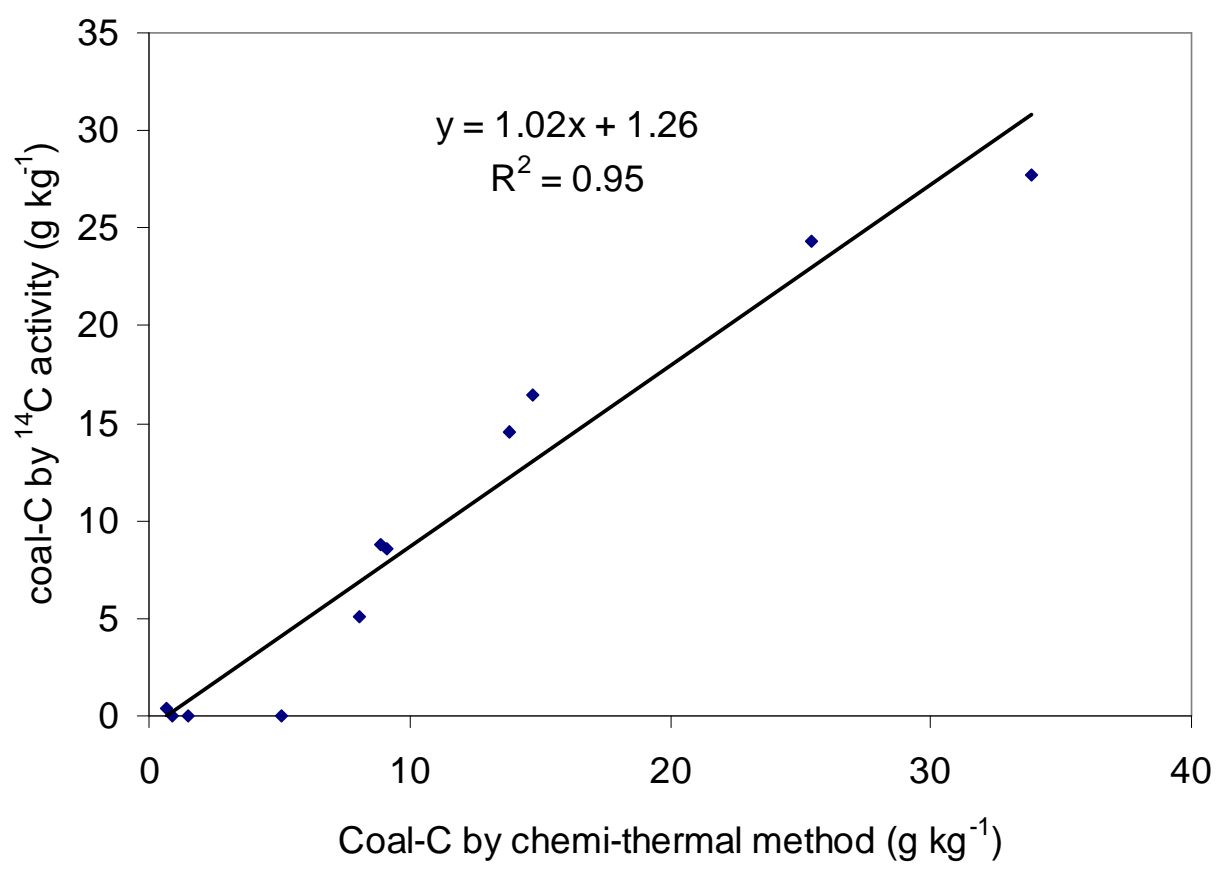

Figure 3. Relationship between coal-C fraction of the reclaimed mined soils determined by radiocarbon activity and chemi-thermal method 
4.4 Task 4: Optimum sampling design and distribution of coal particles within the profiles of RMS

\subsubsection{Variability of bulk density, soil $\mathrm{N}$ and different $\mathrm{C}$ fractions in RMS}

Descriptive statistics of the data from pasture, hay, reclaimed hardwood forest, grazing, pine and black locust plantations High Hill and Mount Carmel sites for the bulk density, SIC, SOC and coal-C concentrations from 0-5, 5-10, 10-20, 20-30, 30-40 and 40-50 cm depths are presented in Tables 7, 8, 9, 10 and 11. Bulk density of the reclaimed mined soil ranged from 1.19 to $1.88 \mathrm{Mg} \mathrm{m}^{-3}$, with coefficient of variation (CV) ranges of 0.66 to $22.39 \%$ (Table 7). Bulk densities of the top 0-5 cm depth were generally lower than the deeper depths, probably due to incorporation of soil organic matter from plant detritus near the surface (Table 7). Except Mount Carmel hardwood forest site, generally, bulk density of the subsoil was consistently higher than 1.6 $\mathrm{Mg} \mathrm{m}^{-3}$ recommended for tree establishment (Daniels and Zipper, 1997).

The top $0-10 \mathrm{~cm}$ depths in all sites generally contained very low coal-C fraction (Table 8). This observation agrees with top-soiling reclamation technique which was employed in these sites. After grading the spoil, topsoil (about 20-30 cm depth), which was removed and stored prior to mining is applied. This is normally free of coal contamination. In the sub-soil $(30-50 \mathrm{~cm}$ depth) coal-C was the dominant OC fraction, accounting for nearly 50\% of OC fraction in most sites. The coal $\mathrm{C}$ contents showed high variability in all sites, with the $\mathrm{CV}$ ranging from 6.11 to $112.16 \%$ for all sites. High CV for coal-C fraction could be due to variations in spoil composition, quality of coal and mining and reclamation techniques involved. Overall, mean and median values of coal-C fraction were not similar in most sites and soil depths (Table 8), indicating that the coal $\mathrm{C}$ data was not normally distributed. 
Table 7. Descriptive statistics for bulk density at different depths in reclaimed sites $\left(\mathrm{Mg} \mathrm{m}^{-3}\right)$

\begin{tabular}{|c|c|c|c|c|c|c|}
\hline Depth & Mean & Median & Std error & $\mathrm{CV}(\%)$ & Maximum & Minimum \\
\hline \multicolumn{7}{|l|}{ High Hill black locust plantation } \\
\hline $0-5$ & 1.32 & 1.32 & 0.11 & 12.01 & 1.43 & 1.21 \\
\hline $5-10$ & 1.64 & 1.64 & 0.01 & 1.25 & 1.65 & 1.62 \\
\hline $10-20$ & 1.77 & 1.77 & 0.04 & 3.20 & 1.81 & 1.73 \\
\hline $20-30$ & 1.71 & 1.71 & 0.03 & 2.31 & 1.74 & 1.68 \\
\hline $30-40$ & 1.81 & 1.81 & 0.01 & 0.66 & 1.82 & 1.80 \\
\hline $40-50$ & 1.71 & 1.71 & 0.13 & 10.52 & 1.84 & 1.59 \\
\hline \multicolumn{7}{|l|}{ High Hill grazing and feeding } \\
\hline $0-5$ & 1.21 & 1.21 & 0.00 & 0.47 & 1.22 & 1.21 \\
\hline $5-10$ & 1.57 & 1.57 & 0.08 & 7.22 & 1.65 & 1.49 \\
\hline $10-20$ & 1.69 & 1.69 & 0.10 & 8.28 & 1.79 & 1.59 \\
\hline $20-30$ & 1.79 & 1.79 & 0.04 & 3.44 & 1.83 & 1.74 \\
\hline $30-40$ & 1.88 & 1.88 & 0.17 & 12.62 & 2.05 & 1.72 \\
\hline $40-50$ & 1.84 & 1.84 & 0.16 & 12.63 & 2.01 & 1.68 \\
\hline \multicolumn{7}{|l|}{ High Hill Pasture } \\
\hline $0-5$ & 1.42 & 1.41 & 0.02 & 2.76 & 1.46 & 1.39 \\
\hline $5-10$ & 1.81 & 1.84 & 0.04 & 4.09 & 1.86 & 1.73 \\
\hline $10-20$ & 1.78 & 1.79 & 0.01 & 1.07 & 1.79 & 1.76 \\
\hline $20-30$ & 1.78 & 1.73 & 0.09 & 8.44 & 1.95 & 1.66 \\
\hline $30-40$ & 1.79 & 1.82 & 0.06 & 6.25 & 1.88 & 1.67 \\
\hline $40-50$ & 1.71 & 1.71 & 0.02 & 1.61 & 1.74 & 1.68 \\
\hline \multicolumn{7}{|l|}{ High Hill Pine plantation } \\
\hline $0-5$ & 1.45 & 1.44 & 0.02 & 2.07 & 1.48 & 1.43 \\
\hline $5-10$ & 1.63 & 1.60 & 0.04 & 4.18 & 1.70 & 1.58 \\
\hline $10-20$ & 1.71 & 1.68 & 0.04 & 3.58 & 1.78 & 1.67 \\
\hline $20-30$ & 1.75 & 1.75 & 0.07 & 6.72 & 1.87 & 1.63 \\
\hline $30-40$ & 1.75 & 1.72 & 0.04 & 3.74 & 1.83 & 1.72 \\
\hline $40-50$ & 1.61 & 1.60 & 0.06 & 6.66 & 1.73 & 1.51 \\
\hline \multicolumn{7}{|l|}{ Mount Carmel Hay } \\
\hline $0-5$ & 1.19 & 1.20 & 0.14 & 19.94 & 1.43 & 0.96 \\
\hline $5-10$ & 1.29 & 1.33 & 0.07 & 9.91 & 1.40 & 1.15 \\
\hline $10-20$ & 1.54 & 1.57 & 0.07 & 8.37 & 1.65 & 1.40 \\
\hline $20-30$ & 1.60 & 1.59 & 0.03 & 3.75 & 1.66 & 1.54 \\
\hline $30-40$ & 1.65 & 1.67 & 0.03 & 2.73 & 1.68 & 1.59 \\
\hline $40-50$ & 1.67 & 1.63 & 0.08 & 7.83 & 1.81 & 1.56 \\
\hline \multicolumn{7}{|l|}{ Mount Carmel hardwood forest } \\
\hline $0-5$ & 1.24 & 1.29 & 0.06 & 8.67 & 1.32 & 1.12 \\
\hline $5-10$ & 1.42 & 1.46 & 0.12 & 14.29 & 1.60 & 1.20 \\
\hline $10-20$ & 1.38 & 1.32 & 0.07 & 8.47 & 1.52 & 1.31 \\
\hline $20-30$ & 1.47 & 1.48 & 0.05 & 6.31 & 1.56 & 1.38 \\
\hline $30-40$ & 1.54 & 1.47 & 0.14 & 15.83 & 1.81 & 1.34 \\
\hline $40-50$ & 1.45 & 1.45 & 0.07 & 6.74 & 1.52 & 1.38 \\
\hline \multicolumn{7}{|l|}{ Mount Carmel pasture } \\
\hline $0-5$ & 1.37 & 1.39 & 0.07 & 9.05 & 1.49 & 1.24 \\
\hline $5-10$ & 1.53 & 1.51 & 0.08 & 9.37 & 1.69 & 1.40 \\
\hline $10-20$ & 1.54 & 1.52 & 0.10 & 10.74 & 1.72 & 1.39 \\
\hline $20-30$ & 1.57 & 1.56 & 0.10 & 11.11 & 1.75 & 1.40 \\
\hline $30-40$ & 1.56 & 1.37 & 0.20 & 22.39 & 1.97 & 1.36 \\
\hline $40-50$ & 1.56 & 1.46 & 0.12 & 13.26 & 1.79 & 1.42 \\
\hline
\end{tabular}


Table 8. Descriptive statistics for Coal $\mathrm{C}$ pool at different depths in reclaimed sites $\left(\mathrm{Mg} \mathrm{ha}^{-1}\right)$

\section{Depth}

High Hill black locust plantation

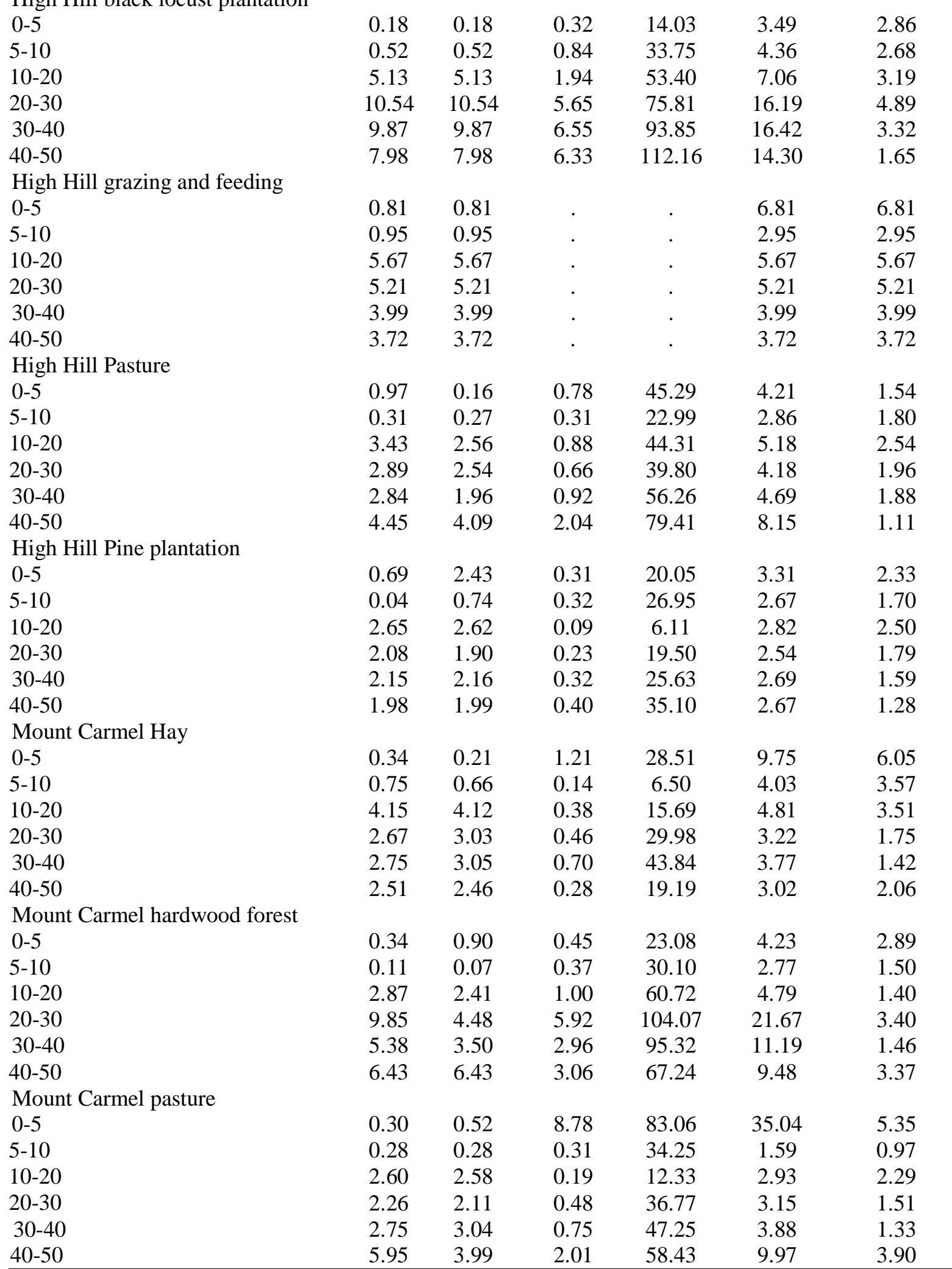


The inorganic C (SIC) median concentrations were generally lower than mean values in most depths (Table 9). In addition, coefficient of variation were also high in these sites, indicating that the SIC is not normally distributed in these sites. The concentrations of SIC generally lower in High Hill and Mount Carmel pasture sites, probably due to N application, which is common practice in the area for increasing fodder quality. The SIC concentration increased with increased soil depth in all sites (Table 9). The variations in SIC could be due to activity of carbonaceous overburden material, which is generally controlled by parent material, rather than mining and reclamation processes.

The distribution and spatial variability of recent SOC in the RMS sites are presented in Table 10. The mean and median SOC concentrations were generally similar, and median concentrations were either equal to or less than the means for most depths (Table 10). The CV for different depths ranged from 0.73 to $81.83 \%$. Overall, SOC exhibited high variability both spatially and by depth, suggesting that sampling protocols employed in undisturbed soils may not be suitable for obtaining the representative samples in these soils. The OC concentrations decreased with increasing depth in all sites, while the variability decreased with increased depth, suggesting that organic matter humification reduces the variability of SOC in the RMS. 
Table 9. Descriptive statistics for inorganic $\mathrm{C}$ pool at different depths in reclaimed sites $\left(\mathrm{Mg} \mathrm{ha}^{-1}\right)$

Depth

High Hill black locust plantation

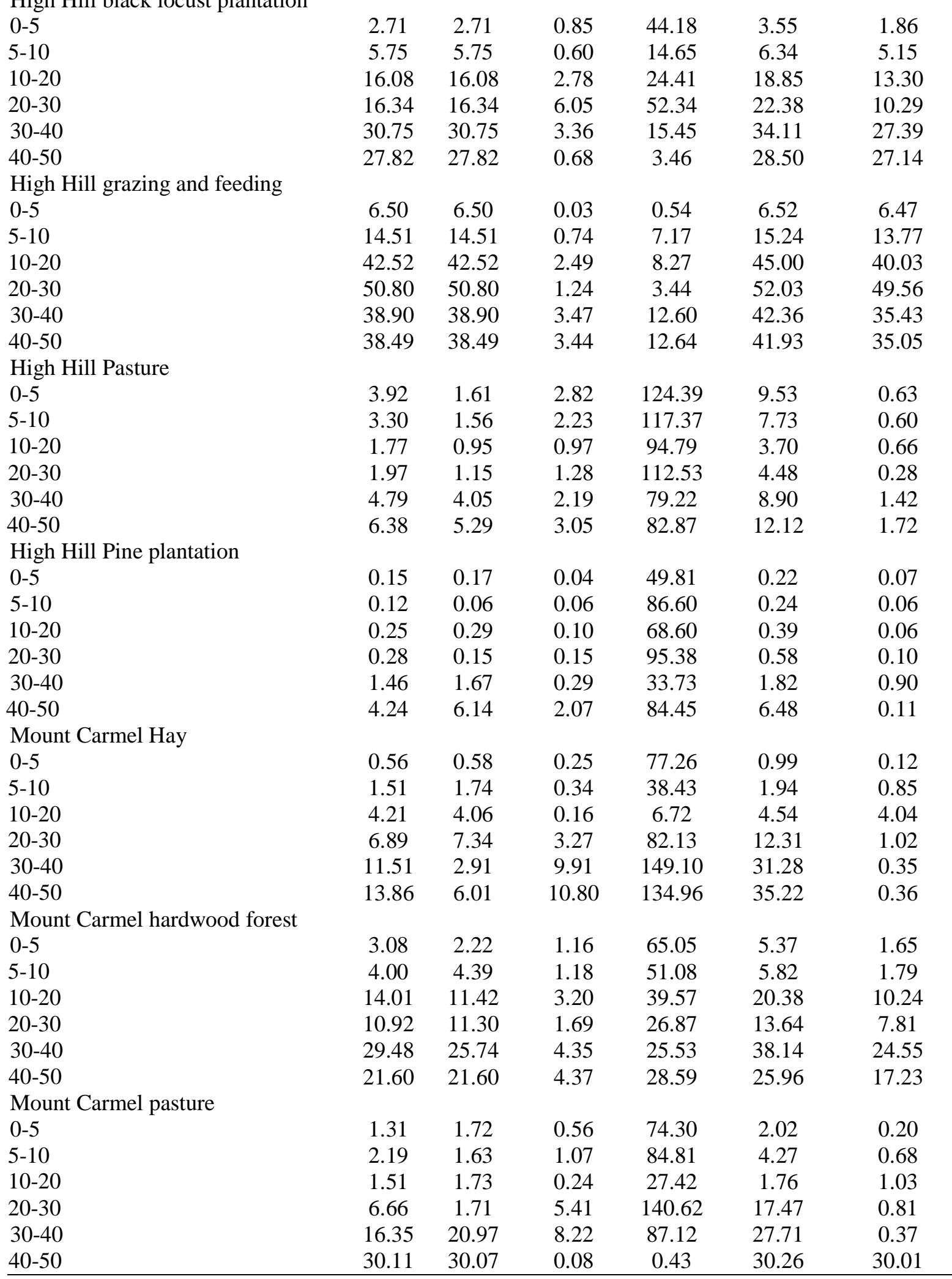


Table 10. Descriptive statistics for SOC pool at different depths in reclaimed sites ( $\left.\mathrm{Mg} \mathrm{ha}^{-1}\right)$

\begin{tabular}{|c|c|c|c|c|c|c|}
\hline Depth & Mean & Median & Std error & $\mathrm{CV}(\%)$ & Maximum & Minimum \\
\hline \multicolumn{7}{|c|}{ High Hill black locust plantation } \\
\hline $0-5$ & 25.04 & 25.04 & 0.32 & 1.78 & 25.35 & 24.72 \\
\hline $5-10$ & 16.94 & 16.94 & 0.53 & 4.42 & 17.47 & 16.41 \\
\hline $10-20$ & 17.26 & 17.26 & 4.23 & 34.63 & 21.48 & 13.03 \\
\hline $20-30$ & 27.57 & 27.57 & 15.39 & 78.94 & 42.96 & 12.18 \\
\hline $30-40$ & 26.26 & 26.26 & 10.07 & 54.21 & 36.32 & 16.19 \\
\hline $40-50$ & 20.51 & 20.51 & 11.94 & 82.33 & 32.45 & 8.57 \\
\hline \multicolumn{7}{|c|}{ High Hill grazing and feeding } \\
\hline $0-5$ & 44.53 & 44.53 & 0.23 & 0.73 & 44.76 & 44.30 \\
\hline $5-10$ & 9.36 & 9.36 & 0.47 & 7.10 & 9.83 & 8.89 \\
\hline $10-20$ & 28.95 & 28.95 & 1.76 & 8.57 & 30.70 & 27.19 \\
\hline $20-30$ & 27.59 & 27.59 & 0.70 & 3.56 & 28.28 & 26.89 \\
\hline $30-40$ & 18.82 & 18.82 & 1.61 & 12.06 & 20.42 & 17.21 \\
\hline $40-50$ & 9.56 & 9.56 & 0.93 & 13.76 & 10.49 & 8.63 \\
\hline \multicolumn{7}{|c|}{ High Hill Pasture } \\
\hline $0-5$ & 24.44 & 22.81 & 3.58 & 25.34 & 31.29 & 19.23 \\
\hline $5-10$ & 12.47 & 13.88 & 1.62 & 22.47 & 14.28 & 9.24 \\
\hline $10-20$ & 13.61 & 13.68 & 0.79 & 10.08 & 14.94 & 12.20 \\
\hline $20-30$ & 8.49 & 8.92 & 0.88 & 17.92 & 9.75 & 6.80 \\
\hline $30-40$ & 9.10 & 8.23 & 1.69 & 32.18 & 12.37 & 6.71 \\
\hline $40-50$ & 6.82 & 6.42 & 1.79 & 45.39 & 10.09 & 3.94 \\
\hline \multicolumn{7}{|c|}{ High Hill Pine plantation } \\
\hline $0-5$ & 19.40 & 19.39 & 0.81 & 7.22 & 20.80 & 18.00 \\
\hline $5-10$ & 12.11 & 12.90 & 1.01 & 14.51 & 13.34 & 10.10 \\
\hline $10-20$ & 15.60 & 15.62 & 0.89 & 9.91 & 17.13 & 14.04 \\
\hline $20-30$ & 10.86 & 10.50 & 0.46 & 7.31 & 11.77 & 10.31 \\
\hline $30-40$ & 11.01 & 11.32 & 1.01 & 15.91 & 12.58 & 9.12 \\
\hline $40-50$ & 6.66 & 7.14 & 1.17 & 30.43 & 8.41 & 4.44 \\
\hline \multicolumn{7}{|c|}{ Mount Carmel Hay } \\
\hline $0-5$ & 33.45 & 33.06 & 4.40 & 22.77 & 41.25 & 26.03 \\
\hline $5-10$ & 17.55 & 17.34 & 1.12 & 11.10 & 19.59 & 15.71 \\
\hline $10-20$ & 18.78 & 16.35 & 2.74 & 25.28 & 24.25 & 15.74 \\
\hline $20-30$ & 10.14 & 10.40 & 0.74 & 12.68 & 11.27 & 8.74 \\
\hline $30-40$ & 10.98 & 11.21 & 1.86 & 29.39 & 14.08 & 7.64 \\
\hline $40-50$ & 10.89 & 9.92 & 1.95 & 31.01 & 14.64 & 8.10 \\
\hline \multicolumn{7}{|c|}{ Mount Carmel hardwood forest } \\
\hline $0-5$ & 21.21 & 18.54 & 3.96 & 32.35 & 29.00 & 16.08 \\
\hline $5-10$ & 13.58 & 11.32 & 2.66 & 33.89 & 18.88 & 10.55 \\
\hline $10-20$ & 15.60 & 14.96 & 2.00 & 22.21 & 19.34 & 12.50 \\
\hline $20-30$ & 0.87 & 0.81 & 0.07 & 14.43 & 1.01 & 0.78 \\
\hline $30-40$ & 23.84 & 21.68 & 2.53 & 18.37 & 28.88 & 20.96 \\
\hline $40-50$ & 24.04 & 24.04 & 13.91 & 81.83 & 37.95 & 10.13 \\
\hline \multicolumn{7}{|c|}{ Mount Carmel pasture } \\
\hline $0-5$ & 53.37 & 57.82 & 15.12 & 49.08 & 77.06 & 25.24 \\
\hline $5-10$ & 6.43 & 6.52 & 0.68 & 18.25 & 7.55 & 5.21 \\
\hline $10-20$ & 9.53 & 10.07 & 0.61 & 11.05 & 10.21 & 8.32 \\
\hline $20-30$ & 7.38 & 7.20 & 0.89 & 20.77 & 9.00 & 5.95 \\
\hline $30-40$ & 10.86 & 10.07 & 2.69 & 42.91 & 15.87 & 6.65 \\
\hline $40-50$ & 13.51 & 14.30 & 1.59 & 20.44 & 15.79 & 10.44 \\
\hline
\end{tabular}




\subsubsection{Soil organic $\mathrm{C}$ and nitrogen pools in different land use}

Soil organic $\mathrm{N}$ pools of the top $0-50 \mathrm{~cm}$ of the RMS under different land use are presented in Fig. 4. Total $\mathrm{N}$ pools were generally greater in pasture $\left(10.18 \mathrm{Mg} \mathrm{ha}^{-1}\right)$, hay $\left(10.61 \mathrm{Mg} \mathrm{ha}^{-1}\right)$ and grazing sites $\left(9.21 \mathrm{Mg} \mathrm{N} \mathrm{ha}^{-1}\right)$ than other land uses. The differences in pools of $\mathrm{N}$ in these sites could be attributed to post-reclamation land management. Pasture, hay and grazing sites generally receives fertilizer $\mathrm{N}$ application at 3 yrs interval. This could impact both $\mathrm{TN}$ accumulation in soil, and increase in biomass production, which will increase soil organic matter input, and hence enhance both $\mathrm{N}$ and $\mathrm{OC}$ content of the soils. The pool of $\mathrm{N}$ in black locust plantation, and hardwood forest was significantly lower than the undisturbed hardwood forest, but significantly higher than the undisturbed grassland (Fig 4).

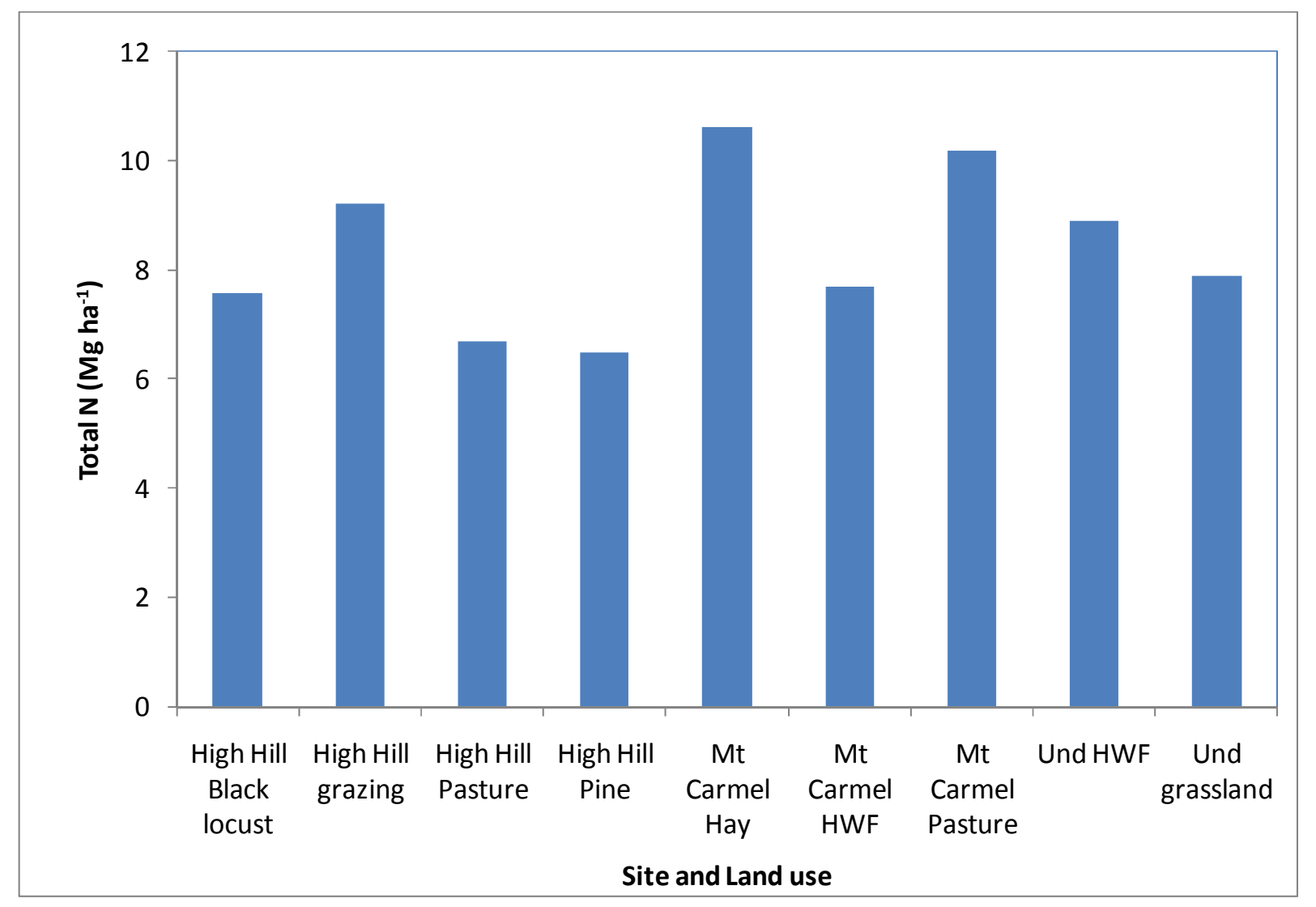

Figure 4. Total $\mathrm{N}$ pool in top $50 \mathrm{~cm}$ of the reclaimed minesoils of Ohio under various land uses 
Soil organic $\mathrm{C}$ pool of the top $50 \mathrm{~cm}$ layer for different land uses are presented in Fig 5. The SOC pool was significantly greater in the black locust plantation and grazing/feeding land uses than pine plantation, pasture and reclaimed hardwood forest. There were no significant differences between black locust and grazing/feeding. In addition, the SOC pool of the hay, reclaimed and undisturbed hardwood forest land use was greater than pine, high hill pasture and the undisturbed grassland site. There were no significant difference between SOC pool in reclaimed hardwood forest and the undisturbed site. Overall, these results indicate that land use plays significant role in controlling SOC and N storage in the RMS. Proper land use selection coupled with best management practices canlead to high levels of SOC sequestration.

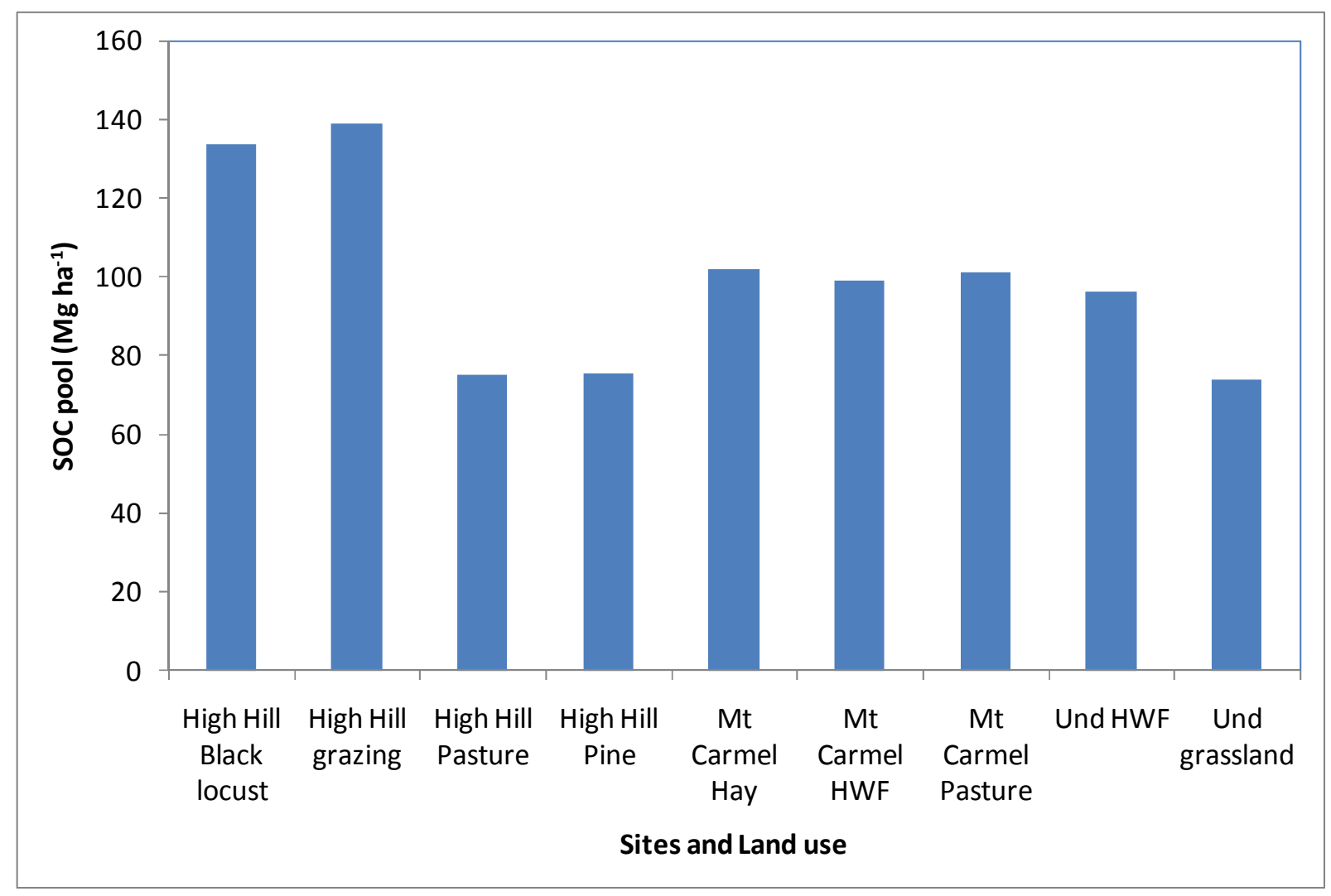

Figure 5. Soil organic $C$ pools in the top $50 \mathrm{~cm}$ of the reclaimed mine soils of Ohio under various land uses. 


\subsubsection{Soil organic carbon pool and sequestration rates}

The SOC concentrations of chronosequence of pasture sites at Cadiz, ranging from 1 to 30 years after reclamation are presented on Table 11. Recent SOC concentration ranged from 1.4 to $29.8 \mathrm{~g} \mathrm{~kg}^{-1}$ (Table 11). The mean recent SOC concentrations decreased with increasing depth in all sites (Table 11). In addition, mean recent SOC concentration increased with increase in age since reclamation in the top $0.2 \mathrm{~m}$ depth, however, concentration was similar for all ages in the subsoil. The SOC pools of the top $40 \mathrm{~cm}$ increased with increased age since reclamation (Figure 6). Using the best fit regression, the relationship between SOC pools and age since reclamation (Age) was logarithmic, with regression equation of:

$$
\mathrm{SOC}=11.15 \ln (\text { Age })+25.3, \mathrm{R}^{2}=0.98 .
$$

Eq 8

The $y$ intercept of SOC sequestration equation represents the estimate of recent SOC pools of the newly reclaimed minesoils, and indicates that the initial SOC pool of the reclaimed sites were 25.3 Mg C ha ${ }^{-1}$. Recent SOC accumulated faster during the first 5 years after reclamation (3.6 $\mathrm{Mg} \mathrm{C} \mathrm{ha}^{-1} \mathrm{yr}^{-1}$ ) than later on. The SOC sequestration rates decreased to $0.5 \mathrm{Mg} \mathrm{C} \mathrm{ha}^{-1} \mathrm{yr}^{-1}$ after 20 yrs. Overall, mean annual sequestration rate for the top $40 \mathrm{~cm}$ for the pasture for the first 30 yrs after reclamation was $1.3 \mathrm{Mg} \mathrm{C} \mathrm{ha}^{-1} \mathrm{yr}^{-1}$ (Table 12). Our data suggest that equilibrium SOC pool was not reached within the period of the age-chronosequence analyzed.

Table 11. Soil organic $C$ concentration of the top $50 \mathrm{~cm}$ in the age chronosequence of pastures in RMS of Northeast Ohio.

\begin{tabular}{cccccc}
\hline \multirow{2}{*}{$\begin{array}{c}\text { Age since } \\
\text { reclamation }\end{array}$} & \multicolumn{5}{c}{ Soil depth $(\mathrm{cm})$} \\
\cline { 2 - 6 } & $0-10$ & $10-20$ & $20-30$ & $30-40$ & $40-50$ \\
\hline & $---------10 \pm 0.76$ & $6.26 \pm 1.01$ & 5.5 & 6.1 & - \\
5 & $13.25 \pm 1.65$ & $5.57 \pm 1.61$ & $4.20 \pm 1.50$ & $3.50 \pm 1.27$ & - \\
10 & $15.32 \pm 1.75$ & $6.607 \pm 0.73$ & $5.60 \pm 0.68$ & $4.29 \pm 0.70$ & 2.89 \\
20 & $18.47 \pm 1.29$ & $8.894 \pm 0.53$ & $7.08 \pm 2.23$ & $3.27 \pm 1.77$ & $2.60 \pm 8.93$ \\
30 & $22.94 \pm 5.98$ & $11.34 \pm 3.34$ & $5.78 \pm 1.35$ & $3.56 \pm 1.73$ & $3.13 \pm 1.75$ \\
\hline
\end{tabular}


Table 12. Recent soil organic carbon sequestration rates established from age chronosequence of pasture from eastern Ohio.

\begin{tabular}{lc}
\hline $\begin{array}{l}\text { Age since reclamation } \\
\text { (yrs) }\end{array}$ & $\begin{array}{r}\text { SOC sequestration rate } \\
\left(\mathrm{Mg} \mathrm{C} \mathrm{ha}^{-1} \mathrm{yr}^{-1}\right)\end{array}$ \\
\hline $0-5$ & 2.7 \\
$5-10$ & 1.9 \\
$10-20$ & 0.8 \\
$20-30$ & 0.7 \\
First 30 yrs & 1.3 \\
\hline
\end{tabular}

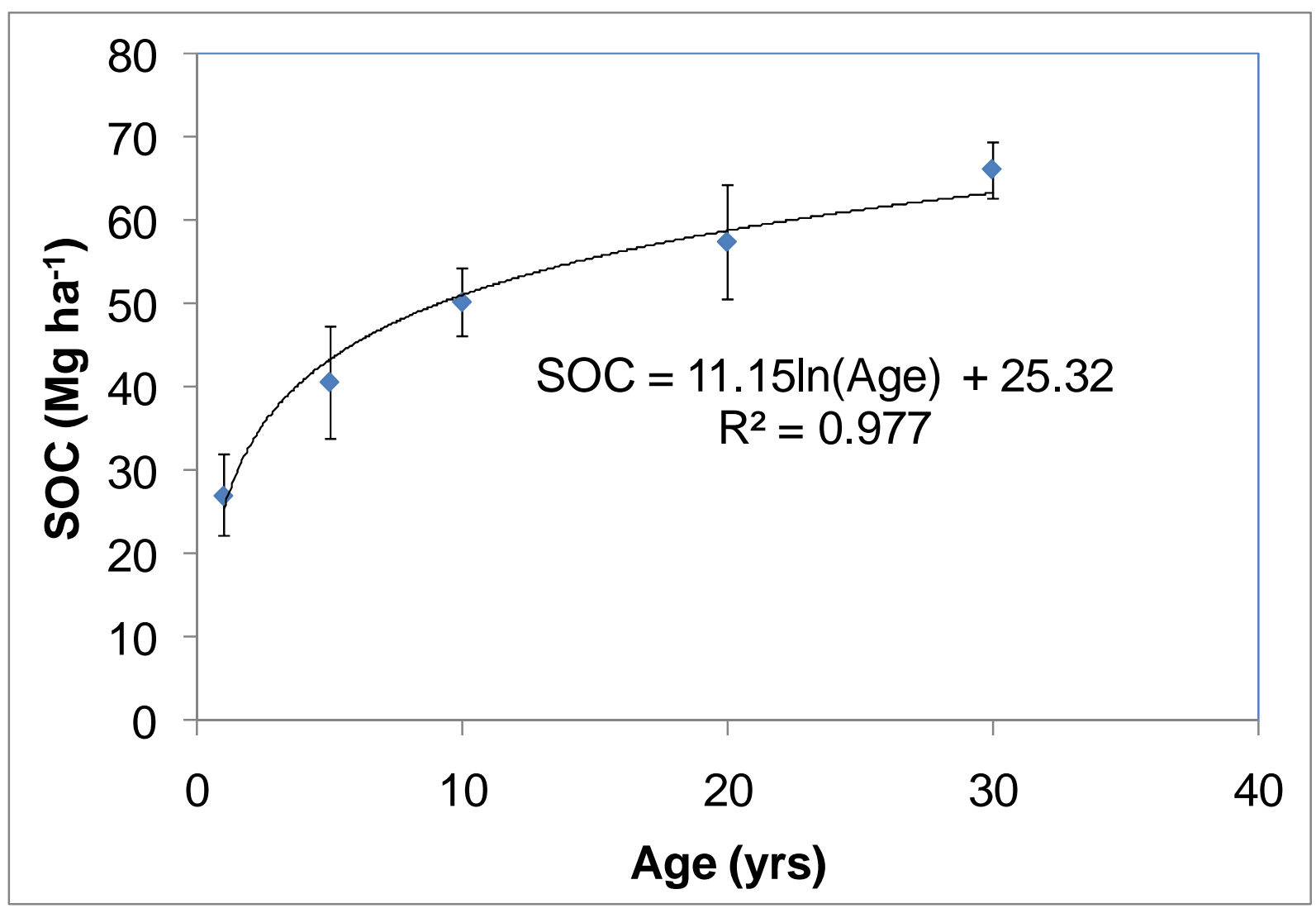

Figure 6. Relationship between site age and SOC

\subsubsection{Microbial biomass $\mathrm{C}$ and mineralizable $\mathrm{C}$}

Microbial biomass $\mathrm{C}$, an indicator of microbial activity in soils, ranged from 0.24 to 1.31 mg C g of soil (Fig. 7). Microbial biomass $\mathrm{C}$ was lowest in one-year old site and increased with increasing age since reclamation. Microbial biomass recovered quickly in the first 10 yrs after 
reclamation in these sites. 10 years after reclamation, the microbial biomass reached $0.98 \mathrm{mg} \mathrm{g}^{-1}$, which is more than $74 \%$ of the 30 -yr old pasture. The rapid recovery of microbial biomass indicated that $\mathrm{C}$ and energy requirements of soil microorganisms were met by fresh organic materials added through newly established grasses. Changes in microbial biomass suggest an increase in microbial population with increased age since reclamation. There was a significant logarithmic correlation between microbial biomass and age since reclamation (Fig. 7). The regression equation of microbial biomass $\mathrm{C}(\mathrm{MBC})$ and age since reclamation:

$\mathrm{MBC}=0.342 \ln ($ Age $)+0.152, \mathrm{R}^{2}=0.94$

Microbial biomass increased at $0.07 \mathrm{mg} \mathrm{g}^{-1} \mathrm{yr}^{-1}$ for the first 10 years and decreased to $0.01 \mathrm{mg}$ after $30 \mathrm{yrs}$. Overall, the microbial biomass increased at the rate of $0.04 \mathrm{mg} \mathrm{g}^{-1} \mathrm{yr}^{-1}$ over the first 30 years since reclamation.

Mineralizable C, an estimate of labile SOC, ranged from 0.55 to $2.53 \mathrm{mg} \mathrm{C} \mathrm{g}^{-1}$ soil (Fig. 7). Mineralizable $\mathrm{C}$ accumulated at rate of $0.19 \mathrm{mg} \mathrm{C} \mathrm{g}^{-1} \mathrm{yr}^{-1}$ for the first 5 years and decreased to $0.02 \mathrm{mg} \mathrm{g}^{-1} \mathrm{yr}^{-1}$ after $30 \mathrm{yrs}$. Changes in mineralizble $\mathrm{C}$ patterns were similar to the microbial biomass $\mathrm{C}$. 


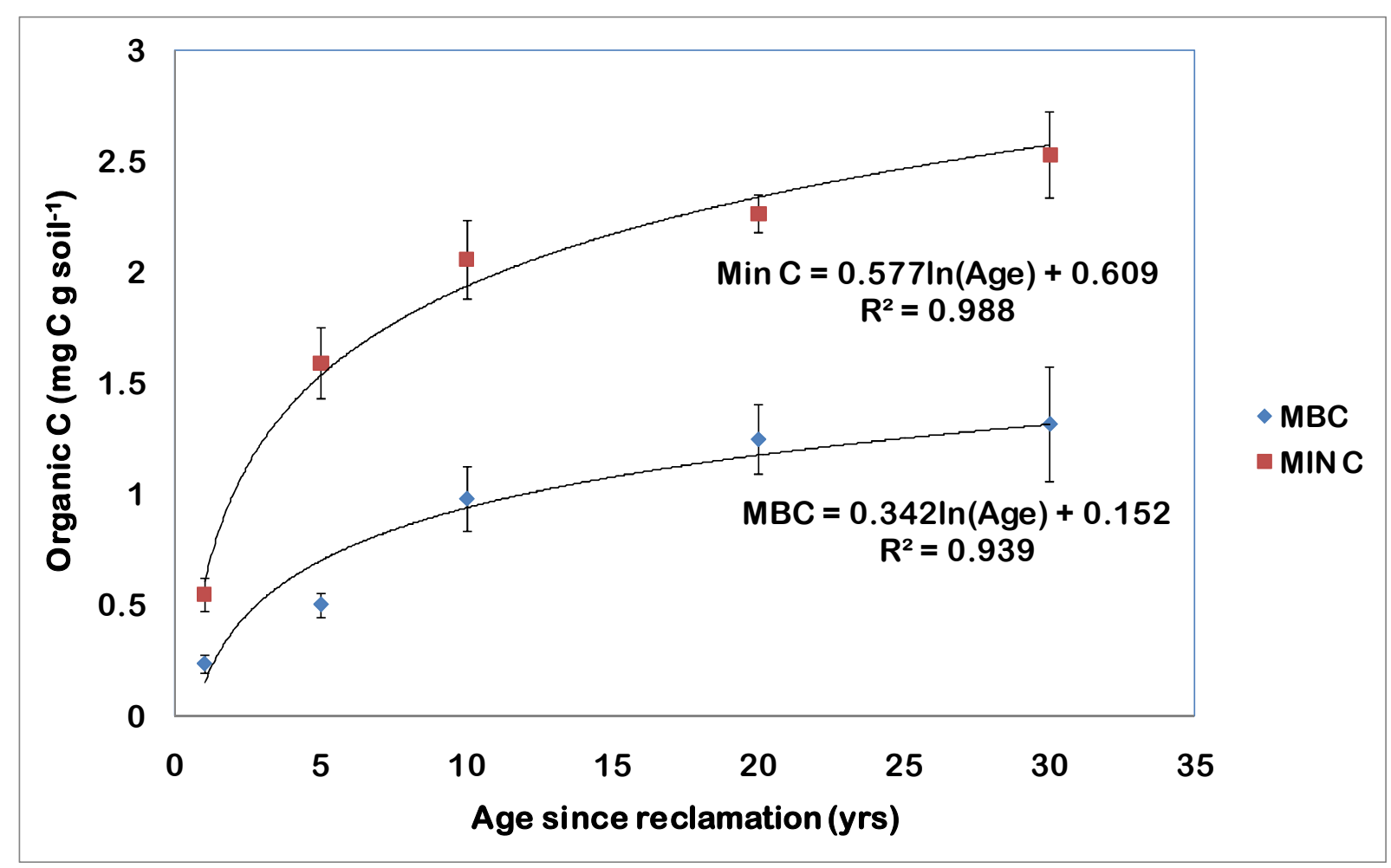

Figure 7. Site age, Microbial and Mineralizable C

\subsection{CONCLUSIONS}

The objectives of this project were to develop the $\delta^{13} \mathrm{C}$ based and chemi-thermal methods for quantifying coal-C fractions in the reclaimed mined soils contaminated with coal particles. Analysis of soil and coal artificial mixtures indicated that the $\delta^{13} \mathrm{C}$ method developed was very effective in estimating coal $\mathrm{C}$ added in the mixtures of soil with naturally labeled with $\mathrm{C} 4$ plants. However, most of the reclaimed sites in Ohio are under $\mathrm{C} 3$ plants with range of $\delta^{13} \mathrm{C}$ signal falling within ranges of coal. The wide range of $\delta^{13} \mathrm{C}$ signal observed in minesoils, (i.e. -26 to -30 for plants and -23 to -26 for coal) limits the ability of this approach to be used for southeast Ohio minesoils. This method is applicable for reclaimed prime farm land under long term corn or corn soybean rotation. Chemi-thermal method was very effective in quantifying coal-C fraction in 
both soil-coal artificial mixtures and minesoils. The recovery of coal-C from the mixture ranged from 93 to $100 \%$ of coal. Cross-validation of chemi-thermal method with radiocarbon analysis revealed that chemi-thermal method was as effective as radiocarbon analysis in quantifying coalC in RMS. Overall, both coal-C and recent OC fraction exhibited high spatial and depth variation, suggesting that approaches used to obtain representative samples in undisturbed soils may not be effective in RMS sites. Analysis of coal-C fraction in RMS indicated that the contribution of coal C to SOC increased with increase in soil depth, accounting for up to $92 \%$ of SOC in the sub-soil. Our data indicated that land use and land management practices plays significant role in enhancing SOC sequestration in reclaimed mined lands.

\section{List of Publications and scientific presentations from this project}

1. Ussiri D.A.N. and Lal, R. Land management effects on properties and C sequestration for the reclaimed prime farmland in northeast Ohio. Soil Science (in preparation)

2. Shrestha, R.K., Ussiri, D.A.N. and Lal, R. Terrestrial carbon sequestration potential in reclaimed mine ecosystem to mitigate the greenhouse effect. Invited book chapter by Soil Science Society of America Inc. Book Title : Agricultural Soils and Carbon Sequestration. (Accepted).

3. Jacinthe P.A. and Lal, R. Carbon storage and minesoil properties in relation to topsoil application techniques. Soil Science Society of America Journal 71:1788-1795.

4. Ussiri, D.A.N., and R. Lal. 2008. Method for coal C determination in the reclaimed minesoils contaminated with coal. Soil Science Society of America Journal 72:231-237

5. Ussiri, D.A.N., R. Lal, and P.A. Jacinthe. 2006. Soil properties and carbon sequestration of afforested pastures in reclaimed minesoils of Southeast Ohio. Soil Science Society of America Journal 70:1797-1806. 
6. Ussiri, D.A.N., R. Lal and P.A. Jacinthe. 2006. Post-reclamation Land use effects on soil properties and carbon sequestration in minesoils of Southeast Ohio. Soil Science 171:261-271

7. Ussiri, D.A.N. and R. Lal. 2005. Carbon sequestration in reclaimed minesoils. Critical reviews in plant Sciences 24: 151-165

8. Ussiri D.A.N. and R. Lal. Microbial biomass and soil organic carbon fractions of the reclaimed agechronosequence of minesoils under pasture in Northeastern Ohio. ASA, CSA, SSSA, Annual International Meetings. November 4-8, 2007.New Orleans, Louisiana.

9. Ussiri D.A.N. and R. Lal. Compaction, Crop and Tillage Effects on Greenhouse Gases Emission From an Alfisol of Ohio. ASA, CSA, SSSA, Annual International Meetings. November 4-8, 2007.New Orleans, Louisiana.

10. Ussiri, D.A.N. and R. Lal. Land use effects on carbon and nitrogen sequestration in reclaimed minesoils of southeast Ohio. ASA, CSA, SSSA, Annual International Meetings. November 1216, 2006.Indianapolis, Indiana.

11. Ussiri, D.A.N. and R. Lal. Comparative analysis of coal carbon content in the reclaimed minesoils of Southeast Ohio, ASA, CSA, SSSA, Annual International Meetings. November 12-16, 2006.Indianapolis, Indiana.

12. Ussiri, D.A.N. and R. Lal. 2005 A method for determining coal carbon content in reclaimed mine soils. Annual meetings, ASA, CSA, SSSA. November 6-10, 2005. Salt Lake City, Utah. 


\section{REFERENCES}

Akala, V.A., and R. Lal. 2001. Soil organic carbon pools and sequestration rates in reclaimed minesoils in Ohio. Journal of Environmental Quality 30:2098-2104.

Balesdent, J., C. Girardin, and A. Marrioti. 1993. Site related delta ${ }^{13} \mathrm{C}$ of tree leaves and soil organic matter in temperate forest. Ecology 74:1713-1721.

Bernoux, M., C.C. Cerri, C. Neill, and J.F.L. Moraes. 1998. The use of stable carbon isotopes for esimating soil organic matter turnover rates. Geoderma 82:43-58.

Chabbi, A., C. Rumpel, P. Grootes, A. Mariotti, and R.F. Huttl. 2006. Isotopic tracer for the analysis of vegetation of vegetation-derived organic matter in lignite-containing soils and sediment along a transect ranging from a forest soil to submerged lake sediment. Org. Geochem. 37:740-753.

Craig, H. 1957. Isotopic standards for carbon and oxygen and correction factors for mass spectroscopic analysis of carbon dioxide Geochimica et Cosmochimica Acta 12:133-149.

Crowell, D.L. 2002. Coal. An educational leaflet no. 8. . Ohio Division of Natural Resources (ODNR).

Cuypers, C., T. Grotenhuis, K.G.J. Nierop, E.M. Franco, A. de Jager, and W. Rulkens. 2002. Amorphous and condensed organic matter domains: the effect of persulfate oxidation on the composition of soil/sediment organic matter. Chemosphere 48:919-931.

Daniels, W.L., and C.E. Zipper. 1997. Creation and management of productive mine soils. Publication 460-121, Virginia Cooperative Extension, Virginia Polytechnic Institute and State University.

DOE. 1999. Carbon sequestration research and development. Office of Science, Office of Fossil Energy, U.S. Department of Energy, Washington, D.C.

EIA. 2006. 2005 Annual coal report. Energy Information Administration, Office of Coal, Nuclear, Electric, and Alternate Fuels, U.S. Department of Energy, Washington, DC.

Farquhar, G.D., Ehleringer, J.R., and Hubick, K.T. 1989. Carbon isotope discrimination and photosynthesis. Annual Review of Plant Physiology and Plant Molecular Biology 40503 537.

Fettweis, U., O. Bens, and R.F. Huttl. 2005. Accumulation and properties of soil organic carbon at reclaimed sites in the Lusatian lignite mining district afforested with Pinus sp. Geoderma 81-91.

Grifith, H. 1992. Carbon isotope discrimination and the integration of carbon assimilation pathways in terrestrial CAM plants. Plant Cell Environment 15:1051-1062

Grossman, R.B., and T.G. Reinsch. 2002. Bulk density and linear extensibility, p. 201-225, In J. H. Dane and G. C. Topp, eds. Methods of Soil Analysis: Part 4. Physical Methods. Soil Science Society of America Inc., Madison, WI.

Haering, K.C., W.L. Daniels, and S.E. Feagley. 2000. Reclaiming mined land with biosolids, manures and papermill sludge, p. 615-644, In R. I. Barnhisel, et al., eds. Reclamation of Drastically Disturbed Lands. American Society of Agronomy/Crop Science Society of America/Soil Science Society of America, Madison, WI.

Indorante, S.J., I.J. Jansen, and C.W. Boast. 1981. Surface mining and reclamation: initial changes in soil character. Journal of Soil and Water Conservation 36:347-351.

Insam, H., and K.H. Domsch. 1988. Relationship between soilorganic carbon and microbial biomass on chronosequence of reclamation sites. Microb. Ecol. 15:177-188. 
IPCC. 2001. Climate Change 2001: The Scientific Basis. Contribution of Working Group I to the Third Assessment Report of the Intergovernmental Panel on Climate Change, Cambridge University Press, Cambridge, United Kingdom and New York, NY, USA.

IPCC. 2007. Climate Change 2007: The Physical Science Basis. Contribution of Working Group I to the Fourth Assessment Report of the Intergovernmental Panel on Climate Change Cambridge University Press, Cambridge, United Kingdom and New York, NY, USA.

Lal, R. 2004. Soil carbon sequestration impacts on global climate change and food security. Science 304:1623-1627.

Lal, R., J.M. Kimble, and R.F. Follett. 1997. Land use and soil carbon pools in terrestrial ecosystems, p. 1-10, In R. Lal, et al., eds. Management of Carbon Sequestration in Soil. CRC Press, Boca Raton, FL.

Lal, R., R.F. Follett, and J.M. Kimble. 2003. Achieving soil carbon sequestration in the United States: A challenge to the policy makers. Soil Science 168:827-845.

Loeppert, R.H., and D.L. Suarez. 1996. Carbonate and gypsum, p. 437-474, In D. L. Sparks, ed. Methods of Soil Analysis: Part 3. Chemical Methods. SSSA, ASA Inc., Madison, WI.

Manning, M.R., D.C. Lowe, M.H. Melhuish, R.J. Sparks, G. Wallace, C.A.M. Brenminkmijer, and R.C. McGill. 1990. The use of radiocarbon measurements in atmospheric studies. Radiocarbon 32:37-245.

Mikutta, R., M. Kleber, K. Kaiser, and R. Jahn. 2005. Review: Organic matter removal from soils using hydrogen peroxide, sodium hypochlorite, and disodium peroxodisulfate. Soil Sci. Soc. Amer. J. 69:120-135.

NMA. 2007. Fast facts about coal.

O'Leary, M.H. 1989. Carbon isotopes in photosynthesis. Bioscience 38:328-336.

Olsson, I.U. 1970. The use of Oxalic acid as a Standard p. 17. In I. U. Olsson, ed. Radiocarbon Variations and Absolute Chronology, Nobel Symposium, John Wiley \& Sons,, New York.

OSM. 2003. Anual report. Office of Surface Mining, Department of Interior. Washington, DC.

OSM. 2004. Anual report. Office of Surface Mining. Department of Interior, Washington, DC.

Rafter, T.A., and J.D. Stout. 1970. Radiocarbon measurements as an index of the rate of turnover of organic matter in forest forest and grassland ecosystems in New Zealand, p. 401-415, In I. U. Olsson, ed. Radiocarbon Variations and Absolute Chronology. Wiley, New York.

Righi, D., H. Dinel, H.R. Schulten, and M. Schnitzer. 1995. Characterization of clay-organicmatter complexes resistant to oxidation by peroxide. Eur. J. Soil Sci. 46:423-429.

Roberts, W.L., W.L. Daniels, J.C. Belll, and J.A. Burger. 1988. Early stages of mine soil genesis as affected by topsoiling and organic amendments. Soil Sci. Soc. Amer. J. 52:730-738.

Rumpel, C., I. KogelKnabner, and R.F. Huttl. 1999. Organic matter composition and degree of humification in lignite-rich mine soils under a chronosequence of pine. Plant and Soil 213:161-168.

Rumpel, C., H. Knicker, I. Kogel-Knabner, and R.F. Huttl. 1998a. Airborne contamination of immature soil (Lusatian mining district) by lignite-derived materials: Its detection and contribution to the soil organic matter budget. Water Air Soil Pollut. 105:481-492.

Rumpel, C., H. Knicker, I. Kogel-Knabner, J.O. Skjemstad, and R.F. Huttl. 1998b. Types and chemical composition of organic matter in reforested lignite-rich mine soils. Geoderma 86:123-142. 
Rumpel, C., J.O. Skjemstad, H. Knicker, I. Kogel-Knabner, and R.F. Huttl. 2000. Techniques for the differentiation of carbon types present in lignite-rich mine soils. Org. Geochem. 31:543-551.

Rumpel, C., J. Balesdent, P. Grootes, E. Weber, and I. Kogel-Knabner. 2003. Quantification of lignite- and vegetation-derived soil carbon using C-14 activity measurements in a forested chronosequence. Geoderma 112:155-166.

Schafer, W.M., G.A. Nielsen, and W.D. Nettleton. 1980. Mine soil genesis and morphology in a spoil chronosequence in Montana. Soil Sci. Soc. Amer. J. 44:802-808.

Schmidt, M.W.I., and A.G. Noack. 2000. Black carbon in soils and sediments: Analysis, distribution, implications, and current challenges. Global Biogeochemical Cycles 14:777793.

Schmidt, M.W.I., H. Knicker, P.G. Hatcher, and I. KogelKnabner. 1996. Impact of brown coal dust on the organic matter in particle-size fractions of a Mollisol. Org. Geochem. 25:2939.

Schmidt, M.W.I., J.O. Skjemstad, C.I. Czimczik, B. Glaser, K.M. Prentice, Y. Gelinas, and T.A.J. Kuhlbusch. 2001. Comparative analysis of black carbon in soils. Global Biogeochemical Cycles 15:163-167.

Schulten, H.R., P. Leinweber, and K.G.T. B. 1996. Characterization of organic matter in an interlayer clay-organic complex from soil by pyrolysis methylation-mass spectrometry. Geoderma 69:105-118.

Sencindiver, J.C., and J.T. Ammons. 2000. Minesoil genesis and classification, p. 595-613, In R. I. Barnhisel, et al., eds. Reclamation of Drastically Disturbed Lands. Soil Science Society of America Inc., Madison, WI.

Seybold, C.A., R.B. Grossman, H.R. Sinclair, K.M. McWilliams, G.R. Struben, and S.L. Wade. 2004. Evaluating soil quality on reclaimed coal mine soils in Indiana pp. 1644-1663, In R. I. Barnhisel, (ed.) Proceedings of Joint Conference of American Society of Mining and Reclamation: 21st Annual National Conference, 25th West Virginia Surface Mine Drainage Task Force Symposium, Morgantown, WV.

Shrestha, R.K., and R. Lal. 2006. Ecosystem carbon budgeting and soil carbon sequestration in reclaimed mine soil. Environment International 32:781-796.

Simpson, M.J., and P.G. Hatcher. 2004. Overestimates of black carbon in soils and sediments. Naturwissenschaften 91:436-440.

Sperow, M. 2006. Carbon Sequestration Potential in Reclaimed Mine Sites in Seven East-Central States. . Journal of Environmental Quality 35:1428-1438.

Stroo, H.F., and E.M. Jencks. 1982. Enzyme activity and respiration in minesoils. Soil Sci. Soc. Amer. J. 46:548-553.

Stuiver, M., and H. Polach. 1977. Discussion: reporting 14C. Radiocarbon 19:355-363.

Stuiver, M., and H. Polach. 1977. Discussion: reporting ${ }^{14}$ C. Radiocarbon 19:355-363.

Ussiri, D.A.N., R. Lal, and P.A. Jacinthe. 2006a. Soil properties and carbon sequestration of afforested pastures in reclaimed minesoils of Ohio. Soil Science Society Of America Journal 70:1797-1806.

Ussiri, D.A.N., R. Lal, and P.A. Jacinthe. 2006b. Post-reclamation land use effects on properties and carbon sequestration in minesoils of southeastern Ohio. Soil Science 171:261-271.

WMO. 2007. World Climate News. No 31 June 2007. World Metrological Organization, Geneva Switzerland. 